Portland State University

PDXScholar

$5-18-1970$

\title{
The Correlation of Factors Relating to the Selection and Retention of Student Teachers at Portland State University
}

Michael E. Carl

Portland State University

Follow this and additional works at: https://pdxscholar.library.pdx.edu/open_access_etds

Part of the Education Commons

Let us know how access to this document benefits you.

\section{Recommended Citation}

Carl, Michael E., "The Correlation of Factors Relating to the Selection and Retention of Student Teachers at Portland State University" (1970). Dissertations and Theses. Paper 602.

https://doi.org/10.15760/etd.602

This Thesis is brought to you for free and open access. It has been accepted for inclusion in Dissertations and Theses by an authorized administrator of PDXScholar. Please contact us if we can make this document more accessible: pdxscholar@pdx.edu. 
AN ABSTRACT OF THE THESIS OF Michael E. Carl for the Master of Sclence presented May 18, 1970.

Title: The Correlation of Factors Relating to the Selection and Retention of Student Teachers at Portland State University. APPROVED BY MEMBERS OF THE THESISCOMMITTEE:

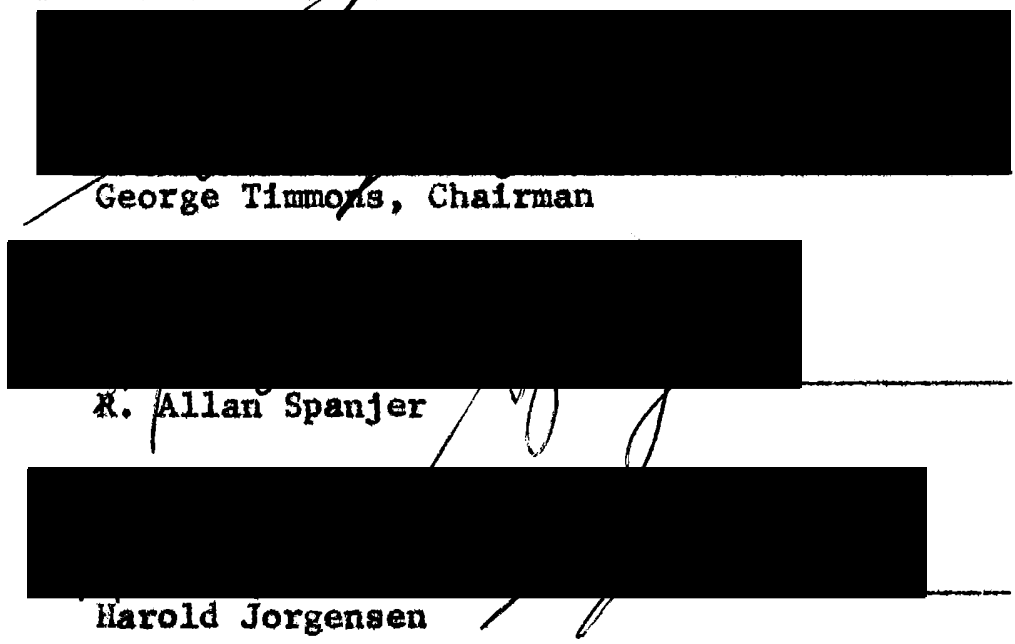

Over the past five years, Increased enrollment in student teachIng at Portland State University has forced the School of Iducation to consider its current guldelines and policles for admitting student teachers. School of Education funding and faculty time are being taxed to meet the demands placed on them by increasing enrollment. This study was undertaken to provide data to determine if and how enrollment In student teaching could be 11mited. To do this, the study examined the existing guidelines for screening and selecting student teachers. The alm of the design was to determine if any of the exist- 
Ing eriterla used in screening correlated wh the student's success 1n student teaching. If the screening criterila did correlate with the student's success, it would be trictly deflned. Th1s would then ald In linting the number of atudente accepted by the school of Education to student teach. If the screaning criteria did not corre1ate, research could begtn from that point. Ihls regearch could be diracted toward findiag criterla that did correlate.

The sample selected for this atudy was mada up of 1,409 student teachere at Portland State UnIversity from Fall Texn 1966 to Spring Term 1969. The qualifications for ach of these atudent teachers, at the time of their screening, were gathered and correlated with the acores each student received for bis atudent teaching expertence. The scoras ued to masure tha student's auccess were taken from the rat-m Inge made by the UnIveralty supervisor, who was ansigned to the atudent teacher. These ecores were concerned with four areas of the atudent' expertence. First, the atudent's knowledge of his subject matter fleld. Second, the student's teaching ability. Third, the student's ability to get along with students and colleagues. Fourth, the atudent's profegetonal and ethleal attitudes.

The data was gathered by reviewing and compling each etudent' qualiflcatione frow records on 11e in the School of Lucation. This data was transferred frow the flle to a data shet which was specially designed for this tudy. From the data sheate the findings were grouped and teated.

The general conclusion of the study was that of the current criteria used in acreening, none correlated at a statietically aigni- 
Elclant leval with the student's success score. A secondary concluston was that of the three grade polnt averages used in sereening, the cumulative average corrolated at higher level than the other two. The interview rating used did not correlate at a signiflcant lovel Wth the success score. Also, the Interview rating did not correlate signifleantly when used to Indicate an macceptablo or outstanding score In student teaching.

From the findings and conclublons several recomendatione were ande In the study. One was that, the screening criteria used by the School of Education be deleted. In 1ts place, an open enroliment polfcy should be adopted by the sehool of Education. To eane the fundIng and the diffeulties, It was recomended that the one to ixteen ratio currently uned in superviston be incrabed. To do this te was auggested thet the clusterligg plan, now being considered by the school of Education be adopted as a plan of action. 
THE CORRELATION OF FACTORS RULATING TO THE SELECTION AWD RETENTION OF STUDENT TEACHERS AT

PORTLAWD STATE UNIVERSITY

by

MICHAEL E. CARL

A thesis submitted in partial fulfillment of the requirements for the degree of

MASTER OF SCIENCE

Portland State University

1970 
To THE OFICE OF GRADUAL SWODLS:

The menbers of the Comittee approve the thesis of

Hchael H. Car1 presented Nay 18, 1970.

\section{George Timmons Chalrman}

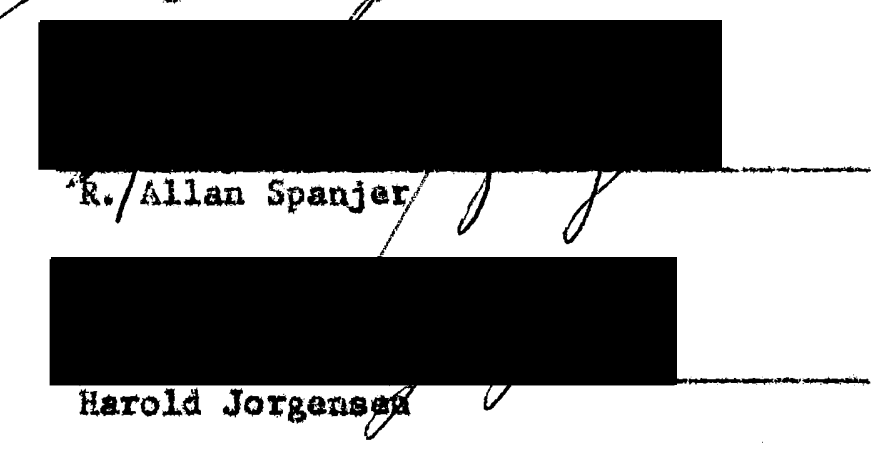

ANRONLD:

Willian A. Jenkins, Dean, School of Education

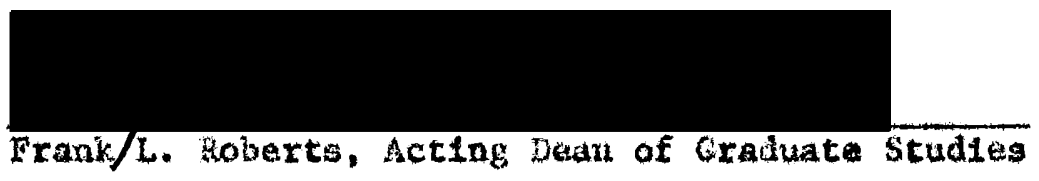

Day 22,1970 
ACKROWLEDGEMENTS

The author wishes to express his thanks to the nabers of his combttee. Also, to the many individuals who gave time and advice to ald hin in this endeavor. 


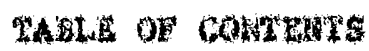

ande

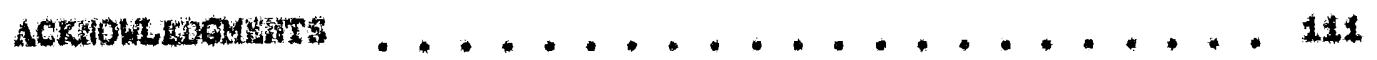

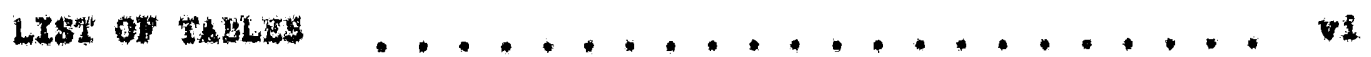

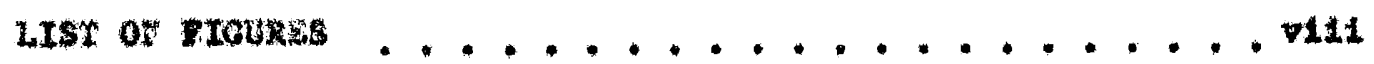

CHAPTER

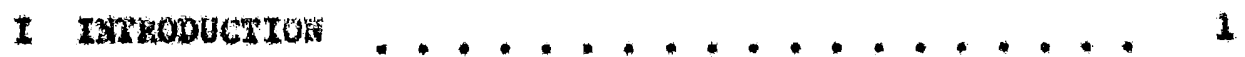

staterat of the Problom ........... 1

Puxpow of the stady ............ 11

scope of the study $\ldots \ldots . . . \ldots 3$

Lisleation of this study .......... 14

Vulut and tuportatice of the study ....... Is

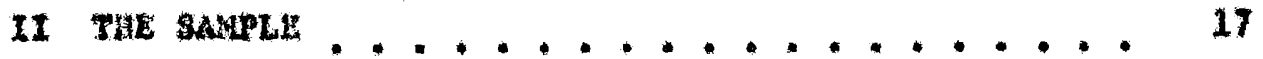

we of the rat ............... 22

Valldty and hallabiltty of the Hownzing

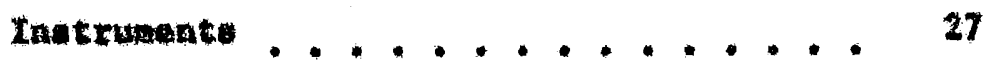

IrI rut protucs .................. 29

Thare I................. 29

Thase II ................. 37

phuse III ................. 49

Phate IV ................ 50

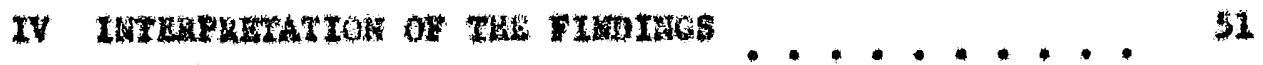

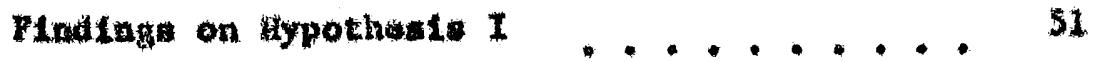


MIndings of Lypotheras II ........... 57

Findings on Hypothesio III .......... 58

FIndings on typothes Is IV and $V . . . . . . .59$

YLualugs on kypothasis VI .............61

v RECOMLERAATIONS ..................... 62

Hypothesis I.................. 62

Hypothesis II.................. 63

Hypothes 1s III ................. 64

Hypothes 1s IV ................ 64

Hyothes1s V.................. 64

Hypothesis VI ................. 64

Add1tional Recomendatione.......... 65

Conclusion ................... 67

Footnotes .............................. 68

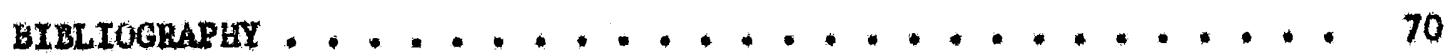

APPENUTX A ............................ 71

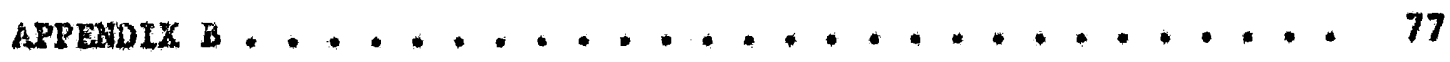

Appundt c .............................. 83

Appandix D.............................. 88

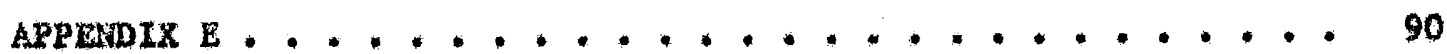

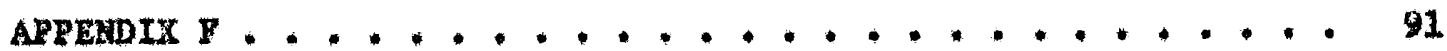

Appentix $6 \ldots \ldots . \ldots . \ldots 2$

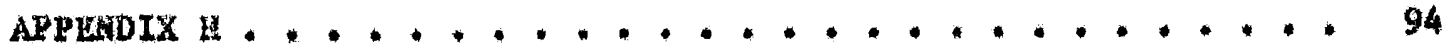

APPERDTX I............................ 96 


\section{LIST OF TABLES}

TABI.

PAGE

I Growth by quarter of the Student Teaching Progratn

at Portland State University, 1965-1970 . . . . 1

II Annual Growth of the Student Teaching Program At

Portland state Univere1ty, 1965-1970 ....... 4

III Number of Student Applying for student Teaching.

Compared to the Number of Students salected to

student teach, 1966-1970 ............ 7

IV Student Teacher Enrollment by Quarter, Fall, 1966-

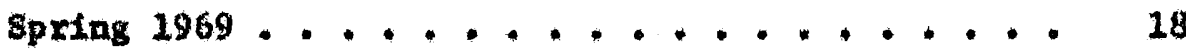

V Student Teachera Grouped by Age, 1966-1969 . . . . . 30

VI Number of Studente Scoring in Groupd Interview Scores,

$1966-1969 . \ldots \ldots 31$

VII Grade Polnt Average Groupings of Student Teachers,

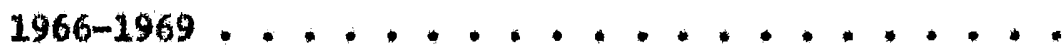

VIII Grouped Student Teacher Scores on IInal Evaluation, 1966-1969...................

IX How Student Teacher Scoras on Final Evaluation Form, $1966-1969 \ldots \ldots 34$

X Scores of Student Teachers on School PInal Evaluation

Forme, 1966-1969................ 
XI Studert Teachers Prepared in subject Mater Flelds,

$$
\text { 1966-1969 .................. }
$$

XII Means, Medans, and Modes, of Items Used In Whase II

$$
\text { of the Data Degigna ................. }
$$

XIII Standard Deviation, quartile Ranges, Quartile

Deviations, and Coefflctentis of Skewness, for

Items Uaed In Phase II of the Data Deatgn.....

XIV Correlation Matrlx for Itema used in Phase II of the Deta Des1ga .....................

XV Correlation of Inal Evaluation Score and Low Interview

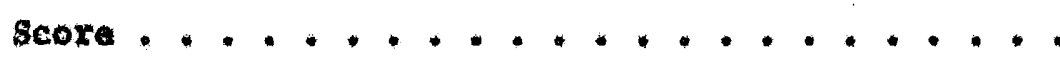

XVI Correlation of Low Hal Bvaluation Score and Interviev

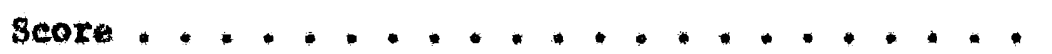

XVII Compared Weang for Deflciency Group and the Total

Sample........................ 
1 Frequency Distributton for the Aren Grade Polnt Avarage , ..., ...............

2 Frequency Distribution for the Professional Grade Polnt Average . . . . . . . . . . . .

3 Frequency Distribution for the Cumulative Grade

Folnt Average $, \ldots, \ldots, \ldots, \ldots$

4 Frequancy Distribution for the Minal Bvaluation

scor ..., ...................

5 Frequency D1stribution for the Subject Natter Seore on the Pinal Evaluation Fora ..........

6 Frequency Distribution for Teaching Abil1ty Score on the Final rvaluation Form .......... 44

7 Frequency Digtributlon for the Ability to Get Along Score on the Final Evaluation Form.......

8 Frequeney DLatribution for the Profuse1onal Attituo Score on the Pinal Evaluation Form ....... 46

9 Frequency Distribution for tile Interviaw score . . . 47

10 Frequency Distribution for the Mdterm and Pinal 
CHAPTER I

INTRODUCTTON

STATEIENT OF THE PROBLIR

This sudy is destgned around several problens currently facing the School of Bducation at Portland State Univeralty. The conditions producing thee problems are outlined in this segrent of tha atudy. The objective 1s to Introduce these problems and to 11lustrate thelr growth and effect on the Sehool of Education.

The first condition has been the rapid increase each year in the number of etudents applying to enter student teaching. student teaching at Portland State University, wthin the School of Education, is required of all students who are seching a state certificate to teach in the public schools of oregon. The tudent teaching experience at Portland State University extends over a full term and applies to most studente within the school of iducation. This study uses the student teachers that student taught between Fall Terw 1965, and Spring Term 1970, ae a sample, to 111ustrate this growth. Table I, and Tuble II, vere comp1led from sehool of Education records extanding over this time period, From Tablo I, 1t can be seen, that from Fall Tern 1965, to Spring Term 1970, the enrollment had increased frow 93 to 217 . This is more than a 200 percent Increase in the enrollment in student teaching. Table I 
TABLE I

GROWTH BY QUARTER OF THE STUDENT TEACHING PROGRAM AT PORTLAHD STATE URIVERSTTY,

1965-1970

\begin{tabular}{|c|c|c|c|c|c|c|}
\hline QUARTER & BL.SI & $\stackrel{3}{\operatorname{Ixche} 1}$ & SEC & $\stackrel{z}{\text { IACRE }} 1$ & $\begin{array}{l}E \& S \\
\text { TOTAL }\end{array}$ & $\stackrel{*}{\text { RKCRE }^{1}}$ \\
\hline F 1965 & 36 & & 57 & & 93 & \\
\hline 1966 & 58 & 37.9 & 59 & 3.3 & 117 & 20.5 \\
\hline S 1966 & 51 & -12.0 & 85 & 30.5 & 136 & 13.9 \\
\hline 1966 & 44 & -13.7 & 49 & -42.3 & 93 & -31.6 \\
\hline พ 1967 & 74 & 45.9 & 67 & 26.9 & 141 & 34.0 \\
\hline$\$ 1967$ & 48 & -35.0 & 84 & 20.2 & 132 & -6.3 \\
\hline 1967 & 44 & -8.3 & 68 & -19.0 & 112 & -15.1 \\
\hline W 1968 & 76 & 42.1 & 73 & 6.8 & 149 & 24.8 \\
\hline \$ 1968 & 76 & 0 & 210 & 33.6 & 186 & 19.8 \\
\hline 1968 & 84 & 9.5 & 75 & -31.8 & 159 & -14.5 \\
\hline * 1969 & 116 & 27.6 & 86 & 12.7 & 202 & 21.2 \\
\hline S 1969 & 104 & -10.3 & 120 & 28.3 & 224 & 9.8 \\
\hline 1969 & 97 & -6.7 & 87 & -27.5 & 184 & -17.8 \\
\hline W 1970 & 138 & 29.7 & 83 & -4.6 & 221 & 16.7 \\
\hline s 1970 & 111 & -19.6 & 106 & 21.7 & 217 & -1.8 \\
\hline TOTAL & 1157 & $6.2^{2}$ & 1209 & $4.2^{2}$ & 2366 & $5.2^{2}$ \\
\hline \multicolumn{7}{|c|}{${ }^{1}$ Percent Increase of one quarter over the preceding quarter. } \\
\hline
\end{tabular}


also shows a steady Increase each tern during this twe period. A percentage rata of Increase colum was computed to masure the growtix of one quarter over the preceding quarter. These percentage rates were totaled and averaged to obtaln a percentage rate, which represented the average rate of 1ncrease each quarter. The resulting figures 11 lustrate the growth pattern and Indicate that the total student tenchlng progran has Increased, on the average, at alightly over five percent each quarter from Fall tarm 1965, to Spring iers 1970.

These statist1ce are also broken down into elementary and secondary student teachers. ${ }^{1}$ The elementary program has increased from 36 studente, Pall Term 1965 to 111 students, Spring Tarm 1970. This represents growth psttern where enroliment Spring Terw 1970 , 1. three times that of Fall Term 1965. At the aecondary level, growth has not been as dranetic howevar, it has more than doubled in the same length of time. At the elementary level there have been more quarters, where the enrollment for one quarter has exceeded the followIng quarter, than at the secondary level. Thus, the average percentage rate of increase on the elementary level exceds that of the secondary leval inerease for the sane time pertod. This means over aix percent rate for the lementary incresse as opposed to over a four percent rate of incraase for secondary majors. The elementary program is increasing at a faeter rate. Five out of the last alx quarters the elamentary enrollwent has exceeded the secondery enrollment. Table II gives further evidence to substantiate and 11lustrate this growth pattern. Table II howe that the annual 1ncrease, as a 
TABL II

ANDUAL GRONWH OR WWE STUDEMT TEACHINO PROGRAM

AT PORTLAND STATE UNIVIRBSTY,

1965-1970

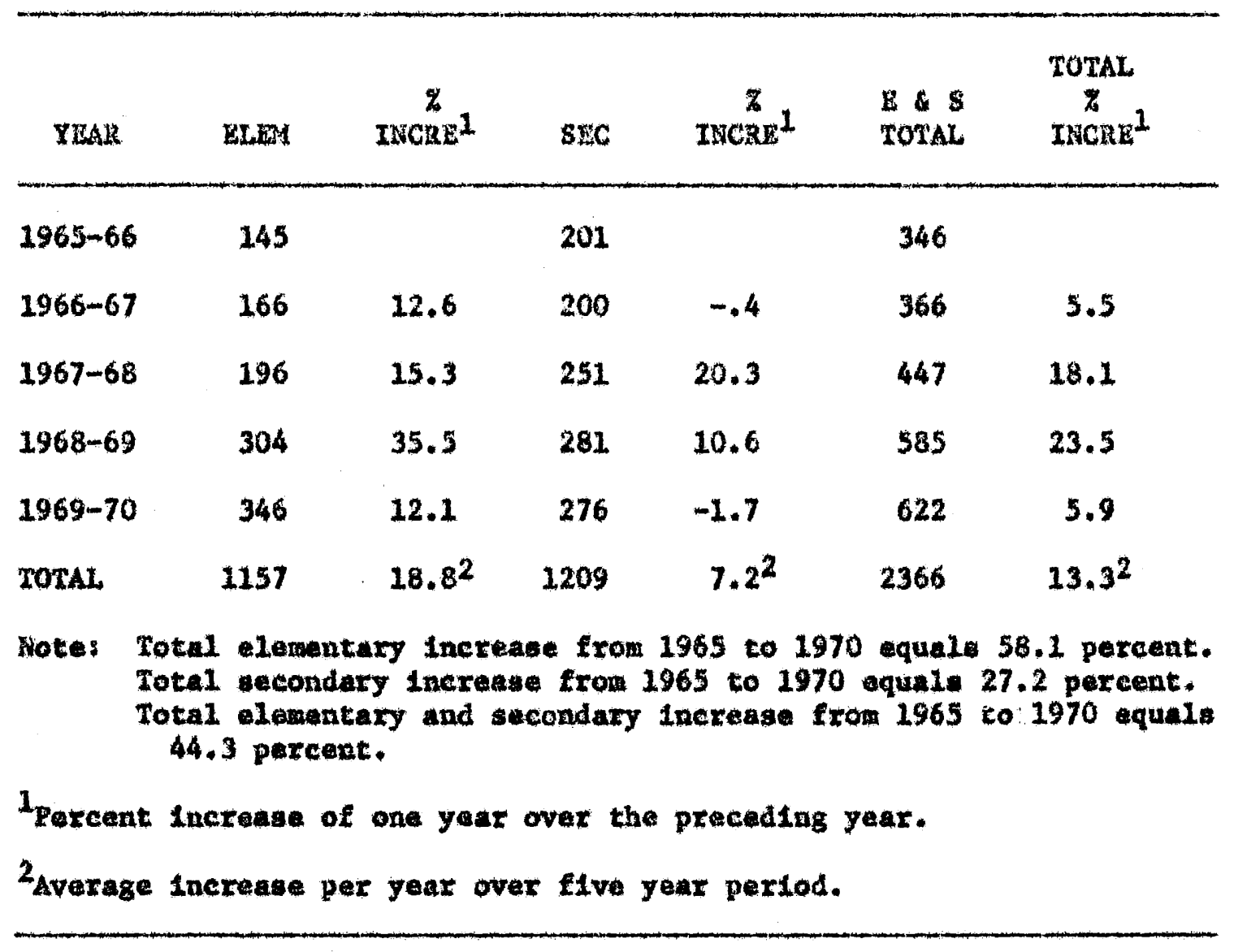

percentage rate, for the alementary level to 18.8 percent. This amounts to over tulce the percentag rate of increase on the secondary level, 7.2 percent. Thus the past two academlc years, 1968-69, and 1969-70; -lenentary enroliment ha exceeded secondary enrollment. On an annual baslo the average rate of increase between alementary and secondary 1. even more revealing. The Increese was over 18 percent on the elementary level as opposed to over a sevan percent lncrease on the secondary level. The average percantage race of Increase per year is also halpful in 11lustrating this growth; as the per quarter increase 
averaged slightly over five percent, as opposed to the annul average rate of Increase which amounted to almost six porcent.

Using these figures for projection purposes, a conservative eatimte would place the anaual entollment in student teaching at Portland State Unfvergity somewhere near 1700 students by 1975. It hould be polnted out that these figureg represent onis the growth in atudent teaching. They do, however, reflect ainilar increages in enrollment whin the School of Education' total progran of studias.

In sumary, this growth pattern for atudent teaching w111 be of fundamental inportance in establiohing the relevancy of this reaearch design. As w111 be shown the imglications and effecto of this incrabsed onrollment have caused meny areas of the student teaching program to be questioned.

In ragard to atudent teaching, the School of Bducation has beon comitted to a student teacher-college supervinor ratio of one aupervinor to every ixteen student teachers. This ratio is arrived at through the applieation of a otate wide formula for class load dietribution and 19 based on quarter hour cotals and numbers of students per quartar hour.

Due to this comitment, and in the face of these increasing numbers of atudents applying for student teaching, many questione are being discused as to the feasibility of the School of Rducation atterapting to matntain this comoltatent. Several School of Education faculty members have stated that this ratio should be lacreased. Several othar faculty menbero have made an alternative suggeation, 
that the enrollment fa atudent taching be curtalled and limited by more effeetve scroenting of applicants. Jndex oxlating guidelines students apt apply for admisston and be adratted to the progran of Studies in Teacher Education (Appendix A, and Appendix B); and then succenefully complete several classes, dealgned to prepare them for teachlng. Thlo must be done before applytng for admisaton to student teaching

Table III was debigned to show the ourrent percentage rate of screenfing applicant Into sudent teachlng. Again, the average number of students not accepted each tera was totaled and averaged. Th1s revealed that, on the average, 15.2 percent of the applicants at the secondary level were being ecreened out of student teaching. Elementary atudent teachers wer being sereened out at the rate of 10.6 percent. It also revealed that, on the avarage, over 12 percent of the applicants for student teaching are not accepted into atudent taaching, Based on the natlonal survey conducted by Dr. Janes Johnson ${ }^{2}$ in 1966-67, 52 percent of the 1netitutions surveyed dented admisation to only two percent or fewer applicants to atudent teaching. Seven pexcent of the Institutions surveyad adaltted all applicants to student taxching. Th1s hows that the School of Education at Portland state UnIversity exceeds the nafority of insticutions acroas the country in the percentage of applicants to whom it currently dentes admisston to sudent teaching.

If enrollment in student teaching is to be linited, there sean to be two logical polnte for this to occur. P1rat, at tha point when a student applies for adriagion to the School of Education; or second, 
TABLEE III

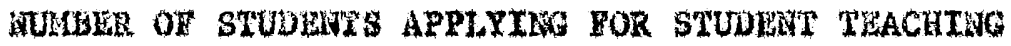
COMPARED TO MUMBER OF STUDERTS SELECTED

TO STUDENT TKACE, 1966-1970

EUISERARY

SECONDARX

BLAM AND SEC

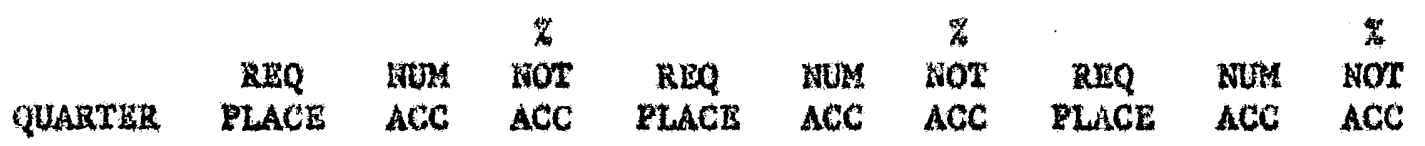

\begin{tabular}{|c|c|c|c|c|c|c|c|c|c|}
\hline 1966 & 58 & 44 & 24.1 & 64 & 49 & 23.4 & 122 & 93 & 23.7 \\
\hline W 1967 & 84 & 74 & 11.9 & 88 & 67 & 23.8 & 172 & 141 & 18.0 \\
\hline S 1967 & 53 & 48 & 9.4 & 97 & 84 & 13.5 & 150 & 132 & 12.0 \\
\hline 1967 & 50 & 44 & 12.0 & 68 & 68 & 0 & 118 & 112 & 5.1 \\
\hline * 1968 & 92 & 76 & 17.5 & 89 & 73 & 17.9 & 181 & 149 & 17.6 \\
\hline 1968 & 85 & 76 & 10.5 & 120 & 110 & 8.3 & 205 & 186 & 9.2 \\
\hline E 1968 & 95 & 84 & 11.6 & 89 & 75 & 15.7 & 284 & 159 & 13.5 \\
\hline 1969 & 126 & 116 & 7.9 & 96 & 86 & 10.6 & 222 & 202 & 9.0 \\
\hline \& 1969 & 119 & 104 & 11.0 & 136 & 120 & 11.7 & 245 & 224 & 11.4 \\
\hline 7 1969 & 104 & 97 & 6.7 & 106 & 87 & 17.9 & 210 & 184 & 12.7 \\
\hline$w 1970$ & 140 & 138 & 1.4 & 112 & 83 & 25.0 & 252 & 221 & 12.3 \\
\hline$\$ 1970$ & 114 & 111 & 2.6 & 123 & 106 & 13.8 & 237 & 217 & 8.4 \\
\hline roxal. & 1110 & 1012 & $8.8^{1}$ & 1188 & 1008 & $15.1^{1}$ & 2298 & 2020 & $12.1^{1}$ \\
\hline AVERAGE & & & $10.6^{2}$ & & & $15.2^{2}$ & & & $12.7^{2}$ \\
\hline
\end{tabular}


when the student applies for admigaion to otudent teachiag.

This atudy Is based on the prewse that nelther of these two positions wil be accepted as pollcy by the school of Fducation. The finding vhould prove helpful in alding the school of Education to determine how 1t can wore effectivaly ocreen and alect poteatially successful student teachers.

Some advantrges can be very clearly seen for wore cfective acreaning at the admission to progran stage, rather than when the student applies for adrission to student teaching. If more students were denied adniesion to student teaching, tudent teaching would becone the control for carollmant in the School of Education. Only the number of efudente who could be superviged, would be admited to the program of atudies, Otherwtse, there would be a large number of students who could not be suparvised beceuse supervioors vould not bo avaliable. More effective screening at this carlier stage would confront the candidate wh the prerequialtes he wat meet, and he rould -111 have time in his academle career to ather, prepare himalf, or seek another career field. This would oeen to be the falrest position to take in light of the etudent's welfare.

Ualng the preceding statements as descriptive of the conditions curranty facing the school of bducation, the following quastions represant 1osuse that posalbly need to be addrased by the faculty of the Behool of Education:

1. How can the Sehool of Education and Fortiand State Untvereity continue to provide supervisory staft to matntain the present one to stxteen gutdelines? 
2. Should the School of Education continue to matntaln the one to sixteen guidelines?

3. Should limita be Imposed upon the number of atudents accepted Into student teaching each tera?

4. How can the School of Education accurately gereen potential tudent teachers?

3. On what date could the curtsilment of enroliment in student teachlng be valldated?

6. What data can most validiy indicate atudents" potentlel for success in student tenching?

This study w11 provide data concerning these 1setues. It is hoped that the date w11 be helpful in providing anowers to some of these 1seucs. It should be pointed out; however, thet this study 18 not dealgned to spectfically provide data only in relation to these 10aces. The bypothesas to bo stated later in this chapter are the focal polnt of the data dealgn.

Curratiy each student who applien for edmisslon to sudent teach1ng must met alx prerequiattes. For purposes of clariflcation these are Ilated below taken frow the, Directione for Compleclas App 11cetion for student reaching or Internghlp form (December, 1969) (Appendix C):

1. Admisgton of etudents to the Program of Studies In Teacher Education. (Appendix A, Appendix B)

2. A minfram cumulative grade point average of 2.50 ; a grade point average of 2.50 in professional courses; 
and a grade point average of 2.25 in axas of

concentration for elementary wors; a 2.50 grade

point average in the teaching major for secondary

ajors.3

3. At least last quarter, junior year standing in collage (123 hours or more).

4. Complation of all prerequisites at atated in the Portland State University catelog, including a mintmum of thirty hours in reaidence. (Appendix A. Appendix B)

5. Hesults of a tuberculosts $x$-tay or tine test showIng absence of comunicable tuberculosis.

6. Approval of a faculty interview conenttee.

of thee exiterta, particular attention has been focused on the Laterview comittee segment (numbar 6 above) of the screening process, Each applicant is required to pase an Interviev before being granted permisaion to tudent teach. Emch Interview tean is composed of three people; a nember of the \$chool of vducation fuculty. a certified maloyed of the public ochools, and a maber of the Portland state University faculty in departmant other than Education.

The Interview has been vlewed by many School of bducation faculty members as possible point where the atudent' potential as a successful atudent teacher and teacher can be 1dentified. It has also bean viewed by averal other faculty members as unnecessary. Thls group feel that any ouppositions or predictions based on the Interview romult are invalid. In lact, the validity of the interview 
comittee's evaluation of a candidate in predicting his success as a student teacher has not heretofore been teated. Thia lack of hard data provides no answers and does littie but perpetuate already axlating coubt and Indectazou.

alde from numbra five and six, the other criteria used for screaning have previously bean dafined with gtrict or loome incexpretation depending primarily on the number of studente applying for - tudent teaching and the Individual student's case. The opportunity for dolng thls way no longer exist as largex numbers of faculty members are required to mcet the demand for supervieton of atudent teachers. The validity of each of the criteria used in screening, is Itportant, as well as predicting whecher or not a tudent is equipped with the animum potentialities to become a suceessul otudent teacher. Along with this, It has becona neceasery to say that sowe atudents on the basts of how their case stands up agadnet the prerequisites to etudent tauch, ohould not be allowed into student teaching. It goes whout saying that ubstantive data is needed to aefend this position.

PURPOSE OF THE STUDY

The Intention of this study is not to support elther the postition of chenging the one to alxteen ratlo, or the screening of a largex percentage of student taaching applicants, as mentioned eariler. It 1. designed to draw conclusions about the valtaity of each of the criteria used to screen atulent teachers. For this purpose the followm Ing elx hypotheses vere developed as a gulde for the alraction of the study. These are stated as follows: 
1. The Interview comittee's evaluation of the candidate has a high correlation in predicting the candidate's success in atudent ceaching.

2. The Interview comittee's evaluation of the candiate has higher valldity than the tudent's grade point average, (sed footnote 3), In predicting the student's probablo auccess in student taaching.

3. Hactors that most Influence a low score 4 in acudent teaching are of a nom-academic nature, e.8., 1ack of comunication ak1118, Inability to control students, at al.

4. Students with grade polnt averages below the minimum raquiremente ${ }^{5}$ do not score at the same level in student teaching.

5. Students admltted to student toaching with deficlene1es, 6 for which valvars are granted, do not have a corresponding Low ocore in atudent taching.

6. The cumulative grade polnt average of a student has a highex validity in predicting algh acore ${ }^{7}$ in atudent reaching aucesse in aecondary grades (9-12) than in elenentery gradea $(1-6)$.

It 1s projected that from the conclustons drawn about each of these hypothoses, racotunandations can be concerning the proviously stated 1ssues facing the School of Iducation. An example is the Intention of this study to deternine the ralidity of each criterion used to screen student teachers. In addition $1 \mathrm{t}$ is proposed that the 
study wlil reveal upon what data students should be daniad or given the opportunity to studant teach. The atudy also hopes to 1dentify those criteria that do not validy Indicate a atudent" probablo success in student teaching.

The tudy also has as a purpose, to provide much needed data to the school of gducation. The research and daka secured for this otudy w111 provide a base frow wich othar research projects can be developed and carried out.

SCOPE OF THE STUDY

For accurate analys purposes, a one gear ample was not constdered satisfactory or oncompassing anough to provide a crosa secton of student teachers. The sample used, as will be defined in more detail in Chapter II, constated of 1,409 utudent teachers at Portland State Univeralty during the period frow Fall texu 1960 to Spring Term 1969. Th1 axcludes those people student texching summer Tera of 1967, 1968, and 1969. This three year sample Included enough cases to provide for accurate analyals.

The scope of the statiatical analysis will reach to eventually correlating the prerequistes for adulsaton to student teaching with a rating scalo designed to numericaliy evaluate oech student teacher ${ }^{\dagger}$ acuccess in otudent teaching (sed footaote 4 and footnote 6 ). The flading of the study w11 epply to the school of Lducation at Rortland state UnIversity. No attempt was made to draw Into the rasearch desigh, date or Infoxation fron other untveralt1es. Quite 


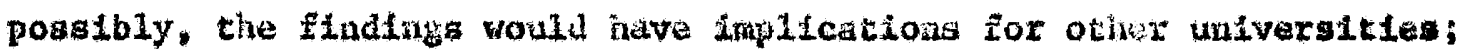
however, the findings ware interpreted only as they applifa to the 1ssues and hypotheses tested in tints dasign.

From the findings, many possible spin-offs could exist. One aueh apin-off could be the ldentiflcation of cotapetencles that seen Important to success ful atudent teaching and teachlag. It is hoped, but not intended, that this resparch could ald in those areas. The student's performance in neeting or not neeting the prerequisites to tudent teaching could Indicate gome areas of coxpetence that a teacher need or need not exhibit.

\section{LIMITATIONS OF THE STUDY}

This study does not inclule an extensive ligting of ilterature as Investigation Into avallable rasources rovalad that vary little research had been done to date in this area. Ap examination of profasional fouruals also ylolded 11ttlo information that related directly to thls study. Whis lack of outside source material could be considered weakness in the design; howevar, a number of factors that could fuetify this 11altation in the study are:

1. That the atudy focuses on afngle tnstitution.

2. That the study is bulle around a serles of lenues and hypotheses that pertain to oze Institution.

3. That no previous reasarch in this area has baen undertakon at Portland State Univergity.

Another possible linitation might be the measureme instrument that 1 uad to Indicete each otudent"s succeas in student 
teaching. The statistical tests done on this instrument (bee page 27) should provide an accurate base from which concluslons can be drawn wth reasonable certalnty. Whe quntity of cases involved and the atatiotical analyeis done on the final evaluation form should eatabilah Its reliability in indicating one student teacher's success as opposed to another student teacher' success. As the aim of the thesis is to correlate those factors used in screenting sudent teachers, there Is a need for some criterla of success in comparing student teachers. This Inmtrument should 1111 that need.

Th1s atudy does not attempt to establiah rellability for the criteria used to acreen student teachers. It does propose to correlate these criteria with soste measure of success. The rollab1lity of grada point avarage and interview acores could easily be the focus of another study.

It is recognized thet the brodd treatmant of the data could make acondary the Importance and conslderation of Individual cases in aelecting student teachers. It is however, one intention of the study to provide date to insure a nore equitable treatment of atudenta. It would seem that leclulone based on accurate statistical ausiyels of dat could better work in the intereste of atudant rether than, in opposition to those interests.

VALUE ART DHPORTANCE OF THE STUDY

The etudy 111 produce data for use in the School of Education In dealing with those proislems nentioned eariler. 
A Large volune of wata that has not been avallable, but needed, will now be avallable For the Sehool of Bucution to use.

Hore effuctive screenitu criterla could result from the findings as well as tho elluination of invalld acreening criterla. Students making applicatolon to the School of Hacktion to do student teaching coula be assured of a more accurate and falr evaluation of their case. Directional decisions could be wate on the basto of findings in this study that will provide for alimination of those teachers that should not ba allowed into taching*

The gtudy w11 suggest several areas where further resuarch is naeded. It should aleo provide basis from which further resarch can be designed. 
CEAPIER II

THE SAMPLE

Fall Term 1966, was selected as the beginning polnt for this study. Inveatigation of earllar years revealed that date avallable prior to thut date was incomplete in many areas, and completely migsing In others. Extenstve data wa found to be avallablo from Fal1 Term 1966. Spring Term 1969, was selectid as the terminal point for the sample used in the study. Using this three year time perlod provided a sample that extended over aine quarters and anounted to 1,409 atudent tancharo.

A shown In Table IV, this divided the eample Into 671 elemantary majors and 738 secondary majors.

The flret tep used in statiotically analyzing the sample vas to code ench of the 1,409 cases on a data olueat (Appendix D). The data sheet was ayetemut1cally developed to provide easy accussibility to the data. The etudent' name (numarieally coded to protect confidentiality), age, tern they student taught, and whether they were en elementury or secondary major, wae coded for case Identification purposes.

The data sheet was divided into geven nuberical sections. The firgt section (Appendix D, Number 1) consisted of three itens, all of which related to the etudent's admisaton to student ceaching. 
TABLE IV

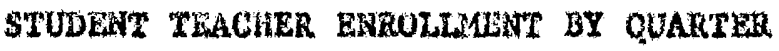

PORTLAND STATE UUEVERISITY

1966 to 1969

\begin{tabular}{|c|c|c|c|c|}
\hline TERE & ELABUTARY & SECONDARY & TOCAL & ACC. TOTAL \\
\hline 1966 & 44 & 49 & 93 & 93 \\
\hline 1967 & 74 & 67 & 141 & 234 \\
\hline s 1967 & 48 & 84 & 132 & 366 \\
\hline F 1967 & 49 & 74 & 123 & 489 \\
\hline W 1968 & 76 & 73 & 149 & 638 \\
\hline S 1968 & 76 & 110 & 186 & 824 \\
\hline 1968 & 84 & 75 & 159 & 983 \\
\hline 1969 & 116 & 86 & 202 & 1185 \\
\hline \& 1969 & 104 & 120 & 224 & 1409 \\
\hline rotal & 671 & 738 & 1409 & 1409 \\
\hline
\end{tabular}

It A was sub-divided into two categories. The student teacher vas coded as degree student if he was an undergraduate and had not completed a bacealaureate degree program. This gxoup also included those studente that had transilerred Into Portland State Univeraity from jubior college or commity collage. The student was coded as a certificate atudent, if he had completed a degree program and wahed to enter student teaching for the purpose of obtaining an Oragon State Teaching Cartifleate. 8

Item of section one establiahod a grade point avarage profile for each case. The grade point averages make up the primary basis 
for preaent seraening of sudent teachers. Wh this fact in mind, the grade point average for each student teacher applicaat was subdivided Into four catogories for wore detalled analyais.

The student' cumblative grade point average (Appendix D), was complled from all the grades he had racelved prior to the term for which he appliad to stuent teach. This cumulative grade polnt average Included any work the student may have completed at another university or 1netitution.

The courses that each atudent is required to complete ouccessfully following hit acceptance luto the school of Education ake up the professional grade polnt average (Appendtx $D$ ). This grade point avarage was complled and computed for each student teaching app 1 lcant. Elementiry education wajor are required to have two subject mattar areas of concentration, wh not less than 30 quarter bours in one and 21 quarter hours in the other. Secondary edweation majora are required to have one bubject matter aran of concantration. This area Lacludes not lass than 36 quarter hours. These grade point averages were coaplled and coded under area grade point average on the data sheet.

Item $C$ of section One coded if an applicant had met all of the prerequiste astefactorily. If he did not, be was coded as having a deficlency. The reasons for the deflelency ware etated, as we11 as, whather a valver was granted for the defletency.

Section Two of the deta aheet coded if the atudent had passed or falled his student teaching experiance. If the student falled a coment was Inserted as to the reason given by his University Supervisor for 
the fallure. In some 1nstances the student teacher was given an incomplate or an extended experfance. Thin normally occura if excessive absentyu due to 11 Iness has been the case. Another Instance for an extendad expexiance would be $1 f$ any question as to the student's passIng or failing still rematned in the mind of the University Supervisor. If either of these were the case it was coded on the data sheet undex Item $B$ of Section Two along with the length of tha extended experience or Incomplete. If an incomplete was given the conditions were otated as to how the Incomplete could be removed by the sudent teacher.

Section Three of the data aheet was deleted from the design a 1 it did not relate to the problam dealt with in the study. A detalled knowledge of the Block Program and some etatiatical means of followiag the Block atudent Into tudent teaching would be necesenry to glve a fatr and objective analyole of this progran, A this design does not deal exclustrely with the Block Program this araa wa deleted from the atudy.

Sections Four and Plve on the data shet were caken from the fInal evaluation form that is f11led out on each student teacher by h1a Unfvare1ty Supervieor (Append1x E). Section Four consisted of the Univeralty Supervitor's name. Section Five la made up of four numerlcal codes that represent the University Superviaor'a assesament of the sucient teacher's abilities and progress during student teaching. The numberlcal code developed for etatistical purposes was a rating scale of one to ten (Appendix F). If a tan wes coded in one of the Lour areas it Indicated that the atudent teacher had recelved the 
highest possible score in that area. A score of one indicated the loweat possible score In that respective category.

The four items within Section Five each code a different competency of the student teacher as a one-to-ten rating. Item One codes the rating glven by the University Supervisor on the student teacher's knowledge of subject matter in his field. Item two codes the student teacher's ability to teach. 9 Item three codes the student teacher's ablilty to get along with other people. Item four codes the student teacher'a professional attitude.

The four Items in Section Five were totaled and averaged. This average or mean was used in the study to represent a score for each student teacher in student teaching.

Section SIX of the data sheet coded the Interview form (Appendix G). Each interview session has three members, who are asked to assess each candidate in ten areas. For statistical purposes the ten categories listed on the interview form were numerlcally coded. A high rating was equivalent to the number three. Average ratings were coded as two, and low ratings were coded as one. If the candidate was Judged unacceptable he was coded as zero. The three interviewers' assessments were totaled and the ten areas were totaled. An average or mean was computed which represented the candidate's score on the interview.

In addition, each of the Interviewers was asked to rate the applicant on a pass or pass with reservations scale. If the candidate was completely unacceptable, the interviewer checked refect on 
the interview fom. These thre ratinge were grouped so that it could be sean whether the candidate was passed, passed with roservation, or rejected by the members of his interview comattrea.

Section Seven on the data sheat caded the classroom supervisor's evaluation of the ocudent teacher. The clasaroom teacher 1s asked to avaluate the atudent teachar tulce durlig the student's expertence, once at midtem (Appendix $M$ ), and once again at the end of the otudent's experience (Appendix I). On the bottor of thase evaluation the classroow suparvieing teacher is requested to rate the atudent on a continuim from unacceptable to excellent on the aldtera form and from unacceptable to outstanding on the final avaluation form. For statiaticul couventence these categortes ware numericsily coded from zoro to four. Four represented outetanding or excellont and zero representing unacceptable.

From these data sheete, group1age were comp1led in each category, end the statietical analyels was done with the objective to eventually correlate the date in several catagories. This would furnteh date to test the hypotheses as stated in the Purpose of che Study in Chapter I.

USE OR THE DATA

A four phave design was developed for the tatiotical analyais of the data. Phese I was to group the data, and then group this data Into more Inclusive grouplngs. Phase 1 consloted of the following grouplngs of the data:

1. The total number of degre students.

2. The total number of certificate students. 
3. The total number of narried students.

4. The total number of single students.

5. The total number of cases.

6. The total number of sudents that fell into the following age grouplage:
a. $20-23$
e. $36-39$
b. $24-27$
f. $40-43$
e. $29-31$
g. $\quad 44-47$
4. $32-35$
b. $48-57$

7. The number of students rated by the interview comittee within the following score ranges:
a. $1.21-1.40$
1. $2,21-2.40$
b. 1.41-1.60
g. $2.41-2.60$
c. 1.61-1.80
h. $2.61-2.80$
d. 1.81-2.00
1. $2.81-3.00$
e. 2.01-2.20

8. The total number of students scoring in the folloring cumulative grade polnt average score ranges:
a. $0.00-2.25$
e. $3.01-3.25$
b. $2.26-2.50$
f. $3.26-3.50$
c. $2.51-2.75$
8. 3.51-3.75
d. $2.76-3.00$
h. $3.76-4.00$

9. The total number of students coring in the following profesatonal grade polat average score ranges: 

a. $0.00-2.25$
e. $3.01-3.25$
b. $2.26-2.50$
f. $\quad 3.20-3.50$
c. 2.51-2.75
g. $3.51-3.75$
d. $2.76-3.00$
h. $3.76-4.00$

10. The total number of atudents scortng 10 the following area grade point average ranges:
a. $0.00-2.25$
2. $3.01-3.25$
b. $2.26-2.50$
f. $3.26-3.50$
c. $2.51-2.75$
8. $3.56-3.75$
d. $2.76-3.00$
h. $3.76-4.00$

11. Number of students coded with deficleucles.

12. The total numbex of gtudents ocoring in the following ranges on the elnal evaluetion form:
a. $1.25-2.00$
f. $6.25-7.00$
b. $2.25-3.00$
8. $7.25-8.00$
c. $3.25-4.00$
h. $\quad 3.25-9.00$
d. $4.25-5.00$
1. $9.25-10.00$
a. $5.25-6.00$

13. The total number of student who had an extended expertence.

14. The total number of students who recelved an incomplete.

15. The total number of ctudencs tho falled.

16. The total numbar of studant who sored in the following ranges on the school evaluation forwe:
a. 4
b. 3
c. 2 

d. 1
e. 0

17. The total nuebex of students who scored in the following ranges on the abject atcer background rating on the Pinal Evaluation sheat:
a. 10
f. 5
b. 9
g. 4
e. 8
h. 3
d. 7
1. 2
e. 6
1. 1

18. The total number of studente who scored In the following ranges on the ceaching ablilty rating on the pinal Evaluation aheat:
a. 10
f. 5
b. 9
8. 4
c. 8
h. 3
d. 7
1. 2
a. 6
1. 1

19. The total number of atudents who scores in the following rangas on the teaching ability rating on the plat Evaluat ton sheet:
a. 10
f. 5
b. 9
8. 4
c. 8
h. 3
d. 7
1. 2
e. 6
J. 1 
20. The total number of students who cored in the following ranges on the professional attitude rating on the rinal Evs Iution sheet:
a. 10
f. 5
b. 9
g. 4
c. 8
h. 3
d. 7
1. 2
e. 6
3. 1

21. The total number of accondary studont teachers grouped by bubject matter area of concentration.

22. The total number of elementary student teachore grouped by oubject matter area of concentration.

Phase II consisted of computing algh statistical figures from Iters 18, 3, 6, and 7, from the data shete For each 1 tem the followIng ctatiotice were computed:

1. Mean

2. Median

3. Node

4. Frequency diatribution

5. Standard deviation

6. Quart1le range

7. Quartile deviation

8. Coefflatent of skewness

Phase III consisted of corralating 1teme $28,5,6$, and 7 on the date whet and obtalning coefflctent of correlation for each wertes. 
Phase IV was to interpret the findings in 11ght of the atx hypotheses orfginally ldentified in Chapter I of the study.

VALIDITY AWO RELIABILITY OF THE MEASURING INSTROMENTS

The measuring inetruments used in this study vere:

1. The cunulative grade point average.

2. The profossional grade point avarage.

3. The area of concentration grade point average.

4. The interview rating sheet.

5. The fland evaluation form.

6. The school evaluation forms.

The purpose of this study is to correlate the prexequisites used In the scroening of student teachers wh the score achieved by the studunt teachex, In atudent taaching. With this in mind, the rallam bility of the cumulative grade polnt average, the profassional grade polnt average, and the area grade polnt average will not be considered In this etudy. Another study would be required for this purpose.

The Intarview rating aheet, and the achool avaluation form: w11 be correlated with the find evaluation forn to establian thetr valldtty and raliability.

The flal evaluation form will be used a valid and reliable Instrument. The following factors partaining to the validity and reliability of this instrument:

1. The number of cases used in the sample. 
2. the analyols of the final evaluation score ditifrution In Chapter III.

3. The langth of time Involved in the sample used in the studiy *

4. The number of balversity Superviacrs (over 30) Iavolved In the ratings.

5. The fact that the University Supervisors vere from the School of Education, other University acadenlc departmenta, and the public schoole.

Wach one of these factors ghould elininate variables that could make the flual evaluation form thvalid and unreliable. Tuking all of these factora into conslderation thio study will use the flnal evaluation form as ascare of how one student tacher scored ta student teachlng a opposad to another atudent teacher.

The question as to whether this forn does measure ablities of taportance; and what specifle abilities are laportant in student tenching, Is considered possible research project that could be carried on from the data eceurad in this scudy. 
CWAPTER III

TIE FIMDLES

The findings w11 be described in four sections. The actions w111 correspond to the four phases of the data analysis design uand In the study.

PHASD I

Phase I was the f1rat statistical treatment of the data followIng It compulation. The objective for Phase I ware threefold:

1. To obtaln wumerical tallies in all the areas ifsted on the data sheet.

2. To group the date for ease in statidically analyzing it.

3. To group the data and develop a dealga for testing each hypothests.

The total sample consiated of 1,409 casas. In ond categories fewer cases were avaliable due to Incomplete data. One example was that during Fal1 Term and Finter $2 \mathrm{er}$ of the 1966-67 acadente gear a different interviet eystem was used for creaning. This reduced the number of cased that could be usad when the Interview was correlated. In a few other Instances the date was not avallable due to incomplete f1les. The number of cases used in each atatistical computation was the largest number of cases avilable with complete data.

The data as gathered in thase I showed that ther were 936 
students, who were enrollad as degree atudents, as opposed to 200 students enrolled as certiflcate students. A total of 537 students were marrled, and 496 ware single.

In the area of ege, the groupings revealed that the wean age of a student teacher at Portland State Ualverstty was 25.714 years. The age breakdown 1s ahown in Table $\mathrm{v}$ below.

\section{TABLE V}

STUDENT TEACELKS GROUPED BY AGE PORTLAND STATE UNIVLRSTTY, 1966-69

\begin{tabular}{cc}
$20-23$ & 603 \\
$24-27$ & 232 \\
$28-31$ & 99 \\
$32-35$ & 35 \\
$36-39$ & 58 \\
$40-43$ & 42 \\
$44-47$ & 26 \\
$48-57$ & 14 \\
\hline
\end{tabular}

The Information in Table $V$ will be helpful, in that, the pean age of student teacher at Portland State UnIveralty seem to be higher than one would expect in school of Education. This could be ignificant when viowed in such areas as the gtudent' ability to get along with other people. It might also be olgutficant in the are of profuseional 
attitudes.

When the tudents were grouped by Interviow scores the numarical totals were shown in Table VI.

TABLE VI

NOMLER OF STUDEWTS SCORING IN GROUPED

IWERVTLW SCORES

NOMBHE OF STUDENTS

$1.21-1.40$

$1.41-1.60$ 7

$1.61-1.80$

$1.81-2.00$

$2.01-2.20$ 88

$2.21-2.40$

213

$2.41-2.60$

233

$2.61-2.80$

169

$2.81-3.00$

184

Table VII shows the findinge when the sudents wero grouped by grade point averages. Table VII Includes all three areas of the grado point average that were used in this otudy. 
TABLE VII

GRGDE POIN AVERAGE GROUP INGS OF STUDZNT TEACHERS

\begin{tabular}{|c|c|c|c|}
\hline $\begin{array}{l}\text { GROUPED GRAUE } \\
\text { POTIT AVERAGE }\end{array}$ & $\begin{array}{l}\text { CUMULAT IVE } \\
\text { of STUDWLTS }\end{array}$ & $\begin{array}{l}\text { PHOFESSIOLAL } \\
\text { " OF STUDEWTS }\end{array}$ & $\begin{array}{l}\text { AREA } \\
\text { OF STUDEXTS }\end{array}$ \\
\hline $0.00-2.25$ & 84 & 33 & 138 \\
\hline $2.26-2.50$ & 224 & 86 & 265 \\
\hline $2.51-2.75$ & 223 & 140 & 314 \\
\hline $2.76-3.00$ & 287 & 289 & 310 \\
\hline $3.01-3.25$ & 150 & 130 & 156 \\
\hline $3.26-3.50$ & 103 & 221 & 147 \\
\hline $3.51-3.75$ & 41 & 122 & 75 \\
\hline $3.76-4.00$ & 7 & 94 & 56 \\
\hline
\end{tabular}

Table VIII howe the flndings when the student teachers were grouped by theix ecores on the final evaluation forw. 
TABLE VIII

GROUPED STUDLRT TEACUER SCORZS

ON FINAL EVALUATION

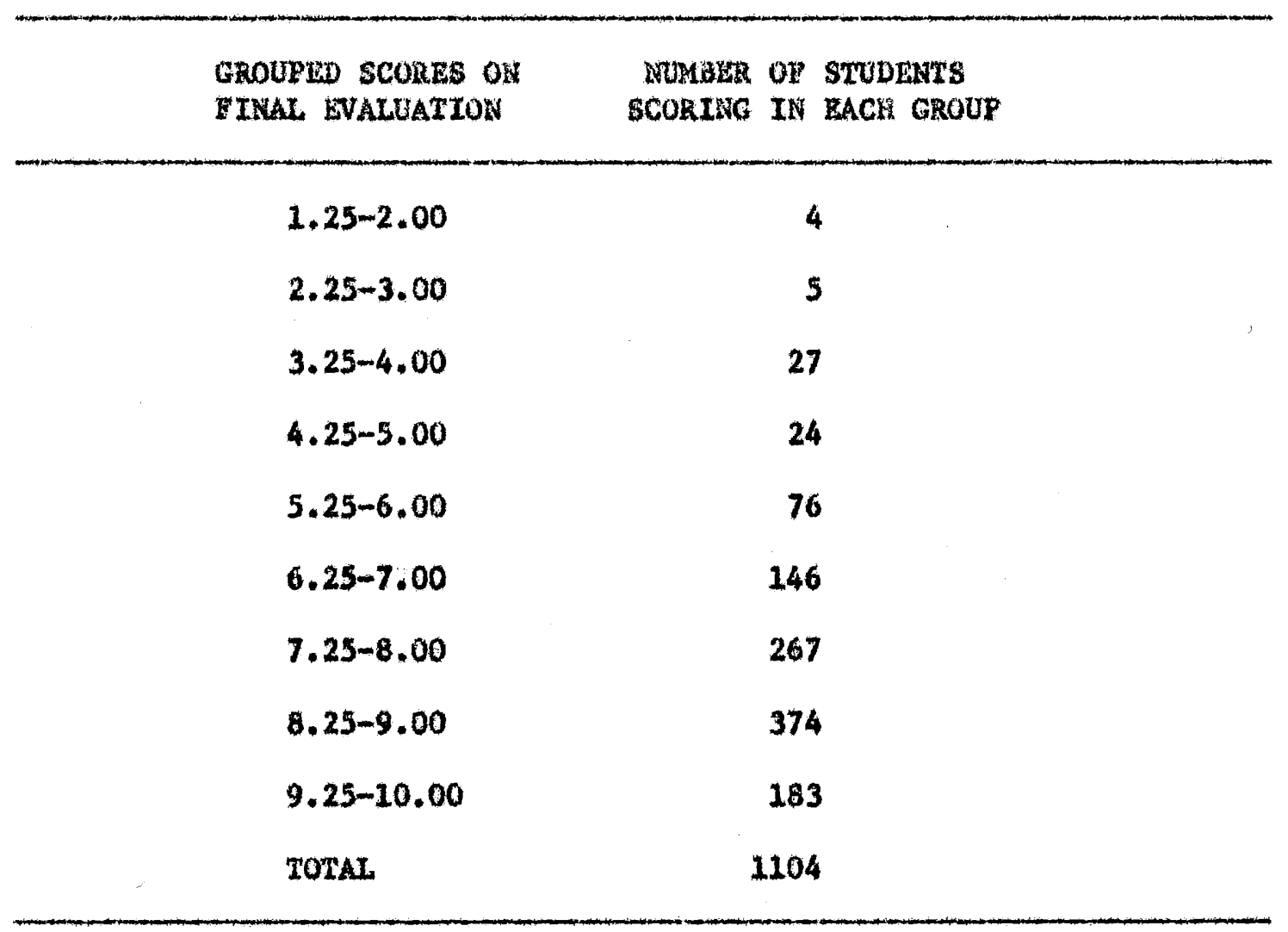

Iable IX shows bow the student teachers scored on ench of the four categorles that were hown on the final evaluation forn. 
TABLE LX

HOW STUDERT TEACHERS SCOADD ON

FIWAL EVALUATION BORM

\begin{tabular}{|c|c|c|c|c|}
\hline SCORE & $\begin{array}{l}\text { SUBJECT } \\
\text { WATTZE }\end{array}$ & $\begin{array}{l}\text { TEACUIWC } \\
\text { ABILITY }\end{array}$ & $\begin{array}{l}\text { ABILIXY TO } \\
\text { GET ALONG }\end{array}$ & $\begin{array}{c}\text { PLOTESS IONAL } \\
\text { ATTITUDES }\end{array}$ \\
\hline 1 & 1 & 1 & 1 & 2 \\
\hline 2 & 3 & 5 & 6 & 5 \\
\hline 3 & 33 & 28 & 13 & 11 \\
\hline 4 & 15 & 27 & 14 & 23 \\
\hline 5 & 28 & 52 & 26 & 30 \\
\hline 6 & 109 & 142 & $\mathbf{1 1 1}$ & 118 \\
\hline 7 & 243 & 210 & 161 & 142 \\
\hline 8 & 252 & 235 & 263 & 251 \\
\hline 9 & 263 & 258 & 323 & 358 \\
\hline 10 & 163 & 152 & 193 & 170 \\
\hline
\end{tabular}

Table $X$ ahows how the student teachers scored on the school final evaluation form. 
TABLE $X$

SCORES OF STUDEHT TEACHERS ON

SCHOOL PINAL EVALUATIOK

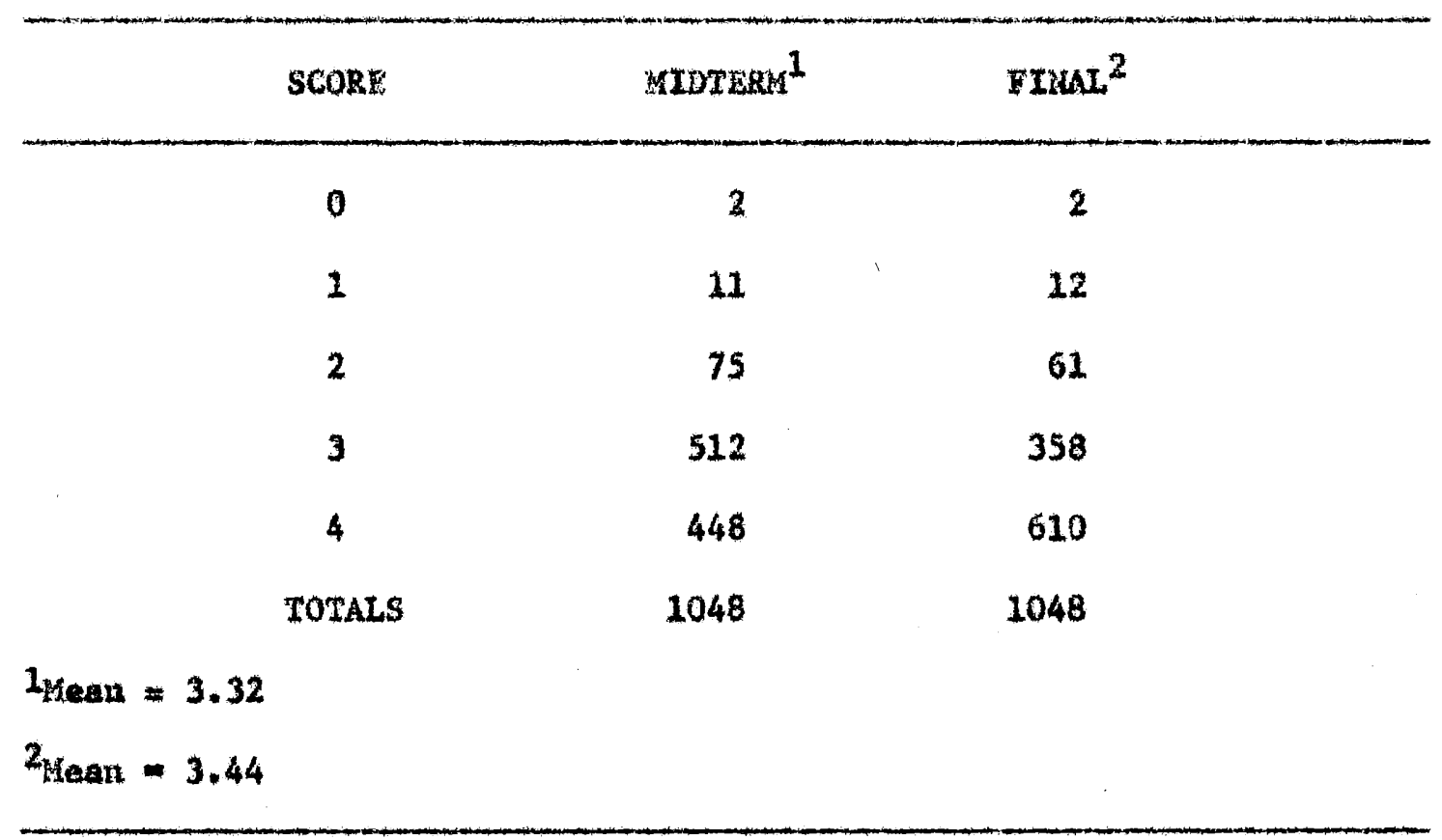

Table XI showe the subject matter areas of the student teachers Included in the otudy. Spectal notice ahould be given that Table XI is not complete and that its value should be Iinfted to proportional compertions and not totale. 
TABLE XI

STUDENI TEACHERS PRETARAN IN

BUBJECT UATIE? FIELOS

1966-1969

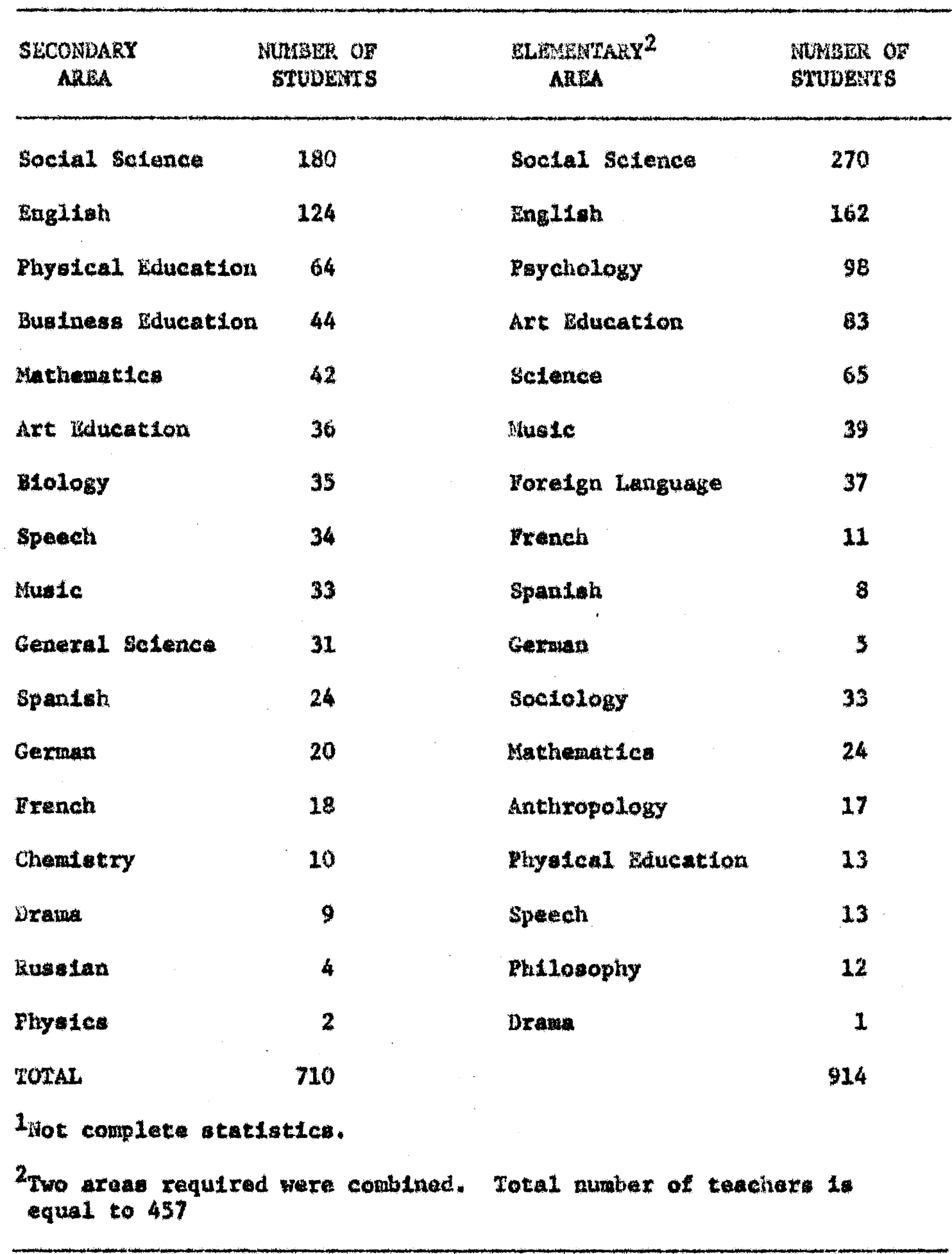


It was also found that 15 stuatents ware givan an extended atudent teachlne experlence durtais this three year period. one hundred twentythree ctudents were allowed to atudent teach with deficlency of one type or another. A totul of 22 students falled their atudent tenching experience.

\section{PHASI II}

Phase II consisted of computing from 1tems 1B, 5, 6, and 7 on the data bheat the following statisties:

1. Mann

2. Median

3. Mocke

4. Frequency dietribution

5. Standard deviation

6. Quartile ranges

7. Quartile deviatlona

3. Coefficient of skemess

Table XII shows the first three of these statistics for aach of the Itome used on the date sheet. 
TASE XII

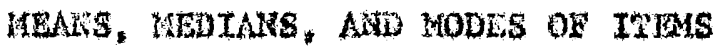

USED IN DATA DESIGN

\begin{tabular}{|c|c|c|c|c|c|}
\hline TITLE & $\begin{array}{l}\text { OT } \\
\text { CASES }\end{array}$ & MEA IV & MEDTAK & MODE & RANGE \\
\hline Area Grade Polnt Average & 1559 & 2.707 & 2.797 & 2.977 & $0-4$ \\
\hline $\begin{array}{l}\text { Profeasional Grade Polnt } \\
\text { Average }\end{array}$ & 1115 & 3.053 & 3.028 & 2.978 & $0-4$ \\
\hline $\begin{array}{l}\text { Cumulative Grade Point } \\
\text { Average }\end{array}$ & 1119 & 2.712 & 2.784 & 2.938 & $0-4$ \\
\hline PInal Evaluation Form & 1104 & 7.832 & 8.256 & 9.104 & $1-10$ \\
\hline Subject Hatter & 1147 & 7.5605 & -1 & -1 & $1-10$ \\
\hline Teaching Ability & 1147 & 7.4167 & -1 & -1 & $1-10$ \\
\hline Ab111ty to Get Along & 1147 & 7.8221 & -1 & -1 & $1-10$ \\
\hline Profesetonal Attitude & 1147 & 7.7759 & -1 & -1 & $1-10$ \\
\hline Intarvier & 966 & 2.4793 & 2.494 & 2.524 & $0-3$ \\
\hline School Mldtem Evaluntion & 1048 & 3.32 & 3 & -1 & $0-4$ \\
\hline Sehool Pinal Evaluation & 1048 & 3.44 & 4 & -1 & $0-4$ \\
\hline
\end{tabular}

Prequency distributions were done on each of the items used on the daca sheets. These are shown in Higures one through ten. 


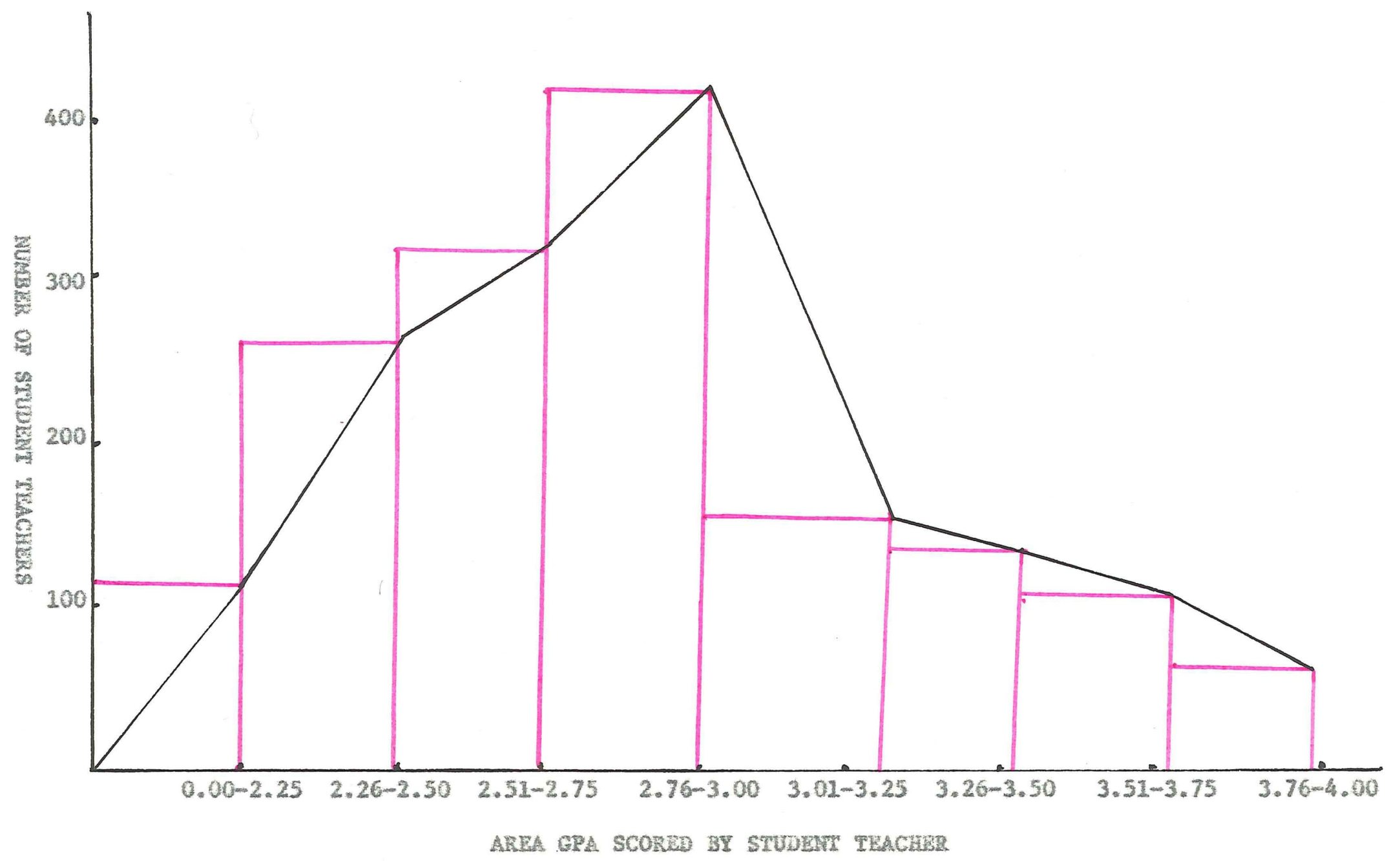

1 Lure 1: Frequency distribution for area grade point average. Hack line represents trend.

$\omega$ 


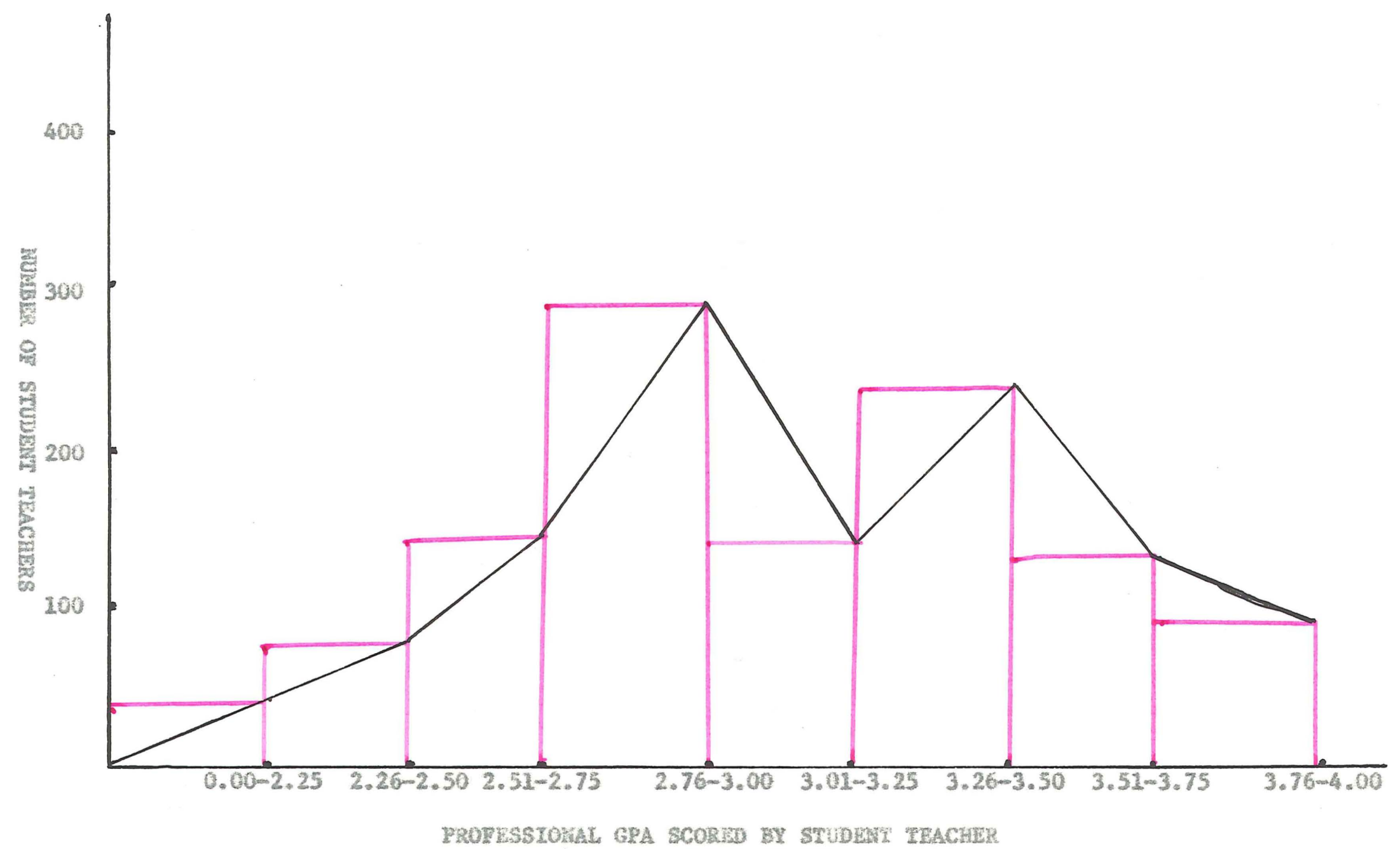

14ure 2: Prequency distrlbution for professlonal grade point average. Black line represents trend. 


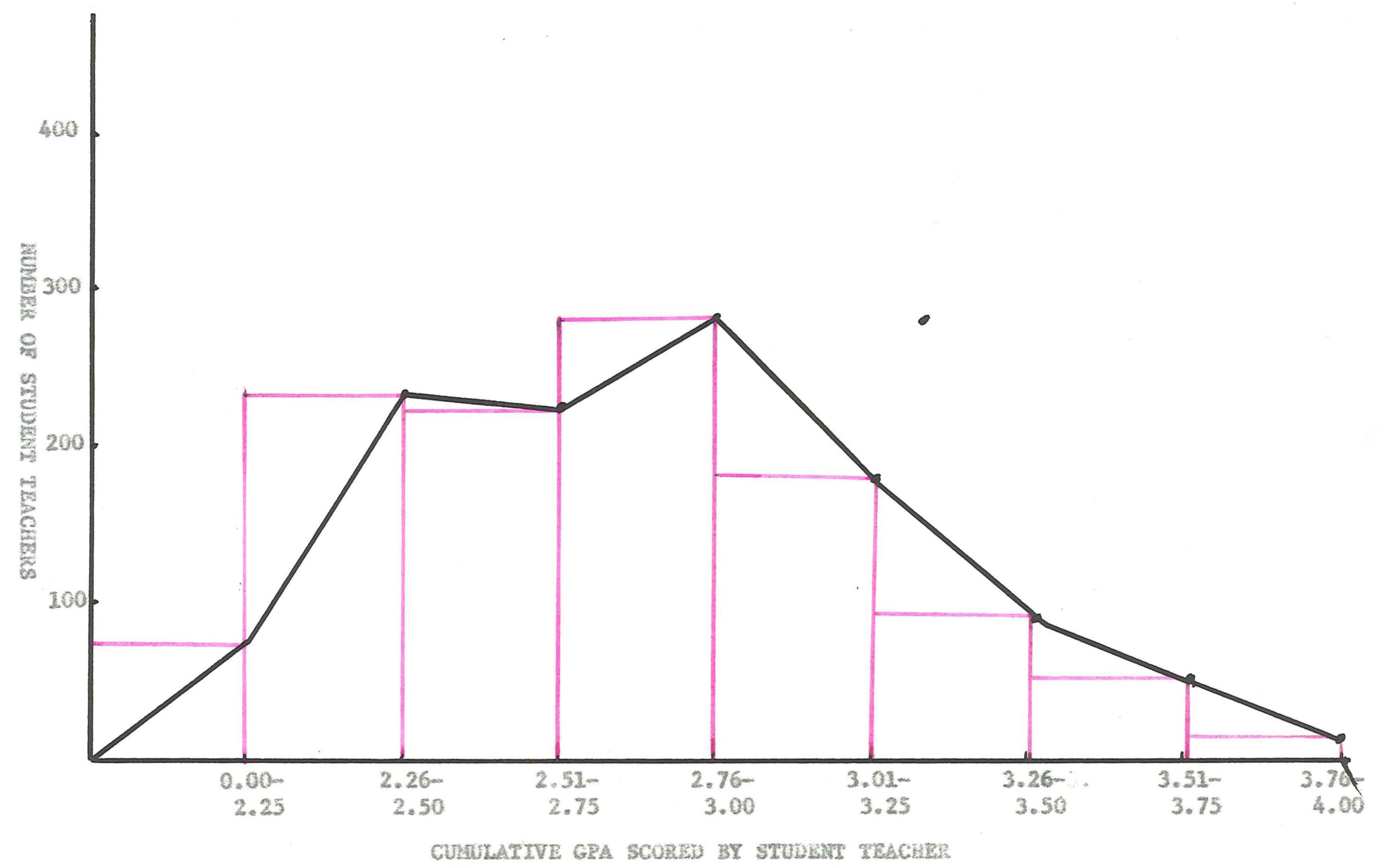

Flgure 3: Frequeney dotribution for cumulative grade polat average. Black line represents trend. 


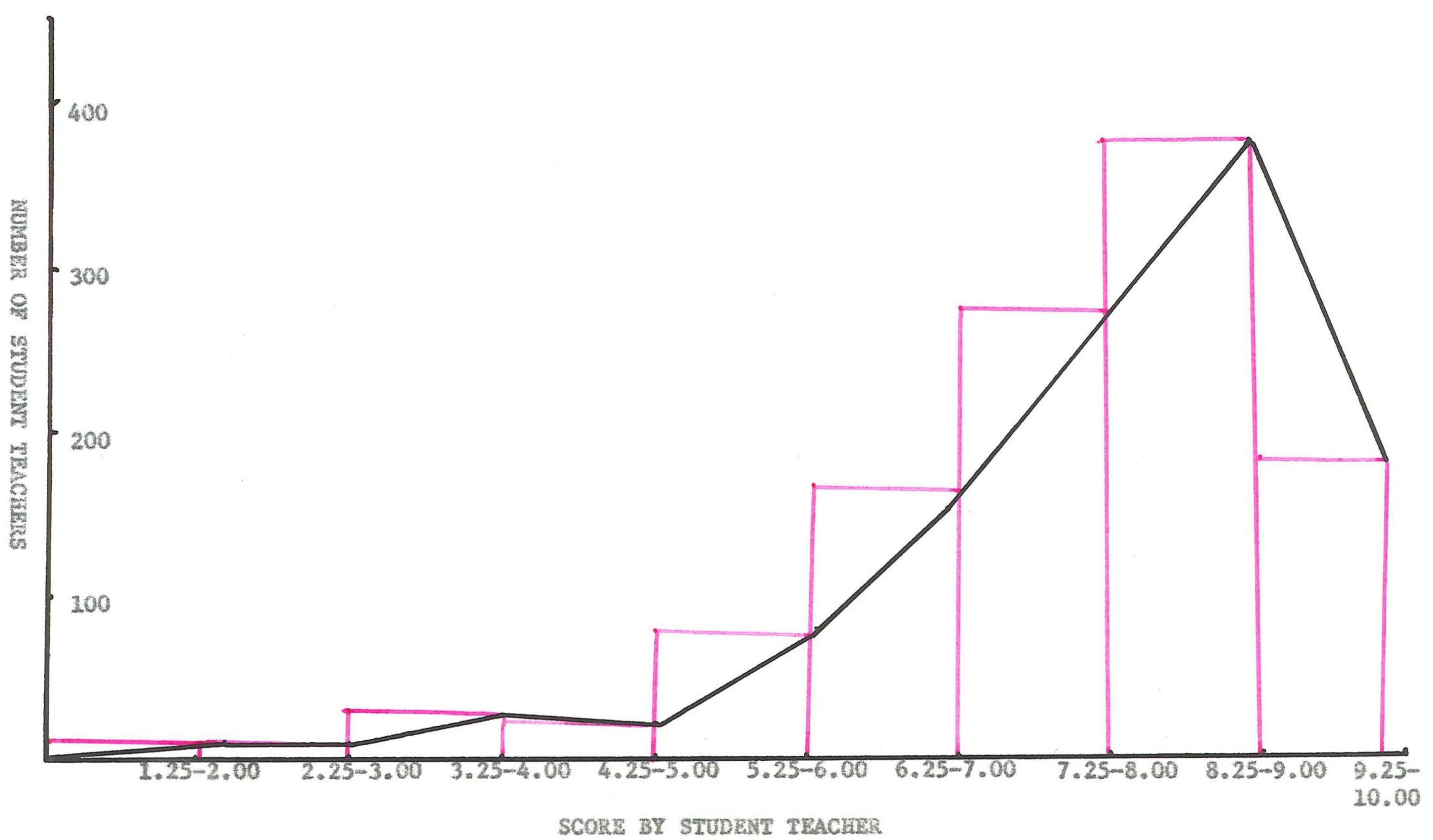

Figure 4: Frequency distribution for flnal evaluation score. 


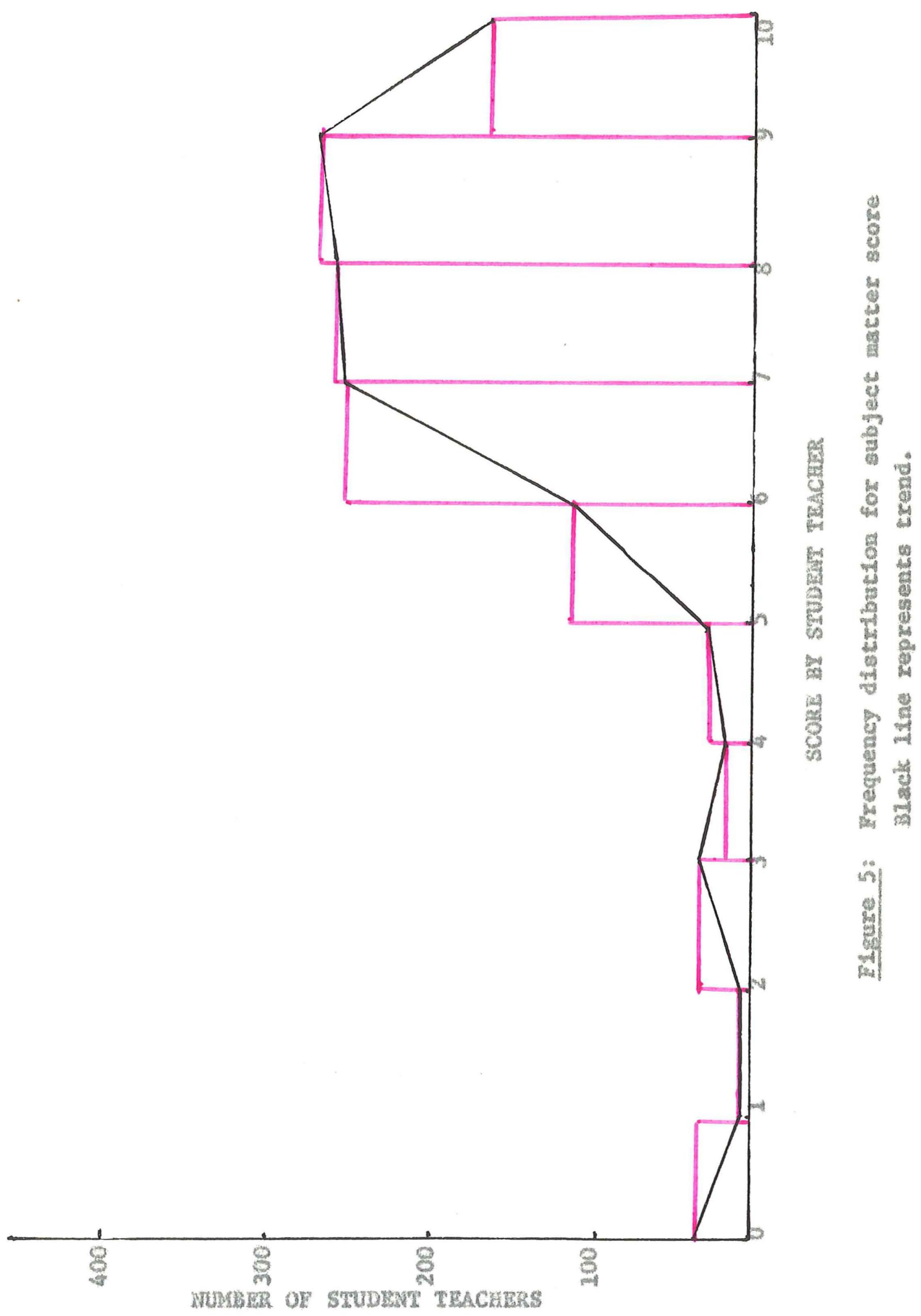




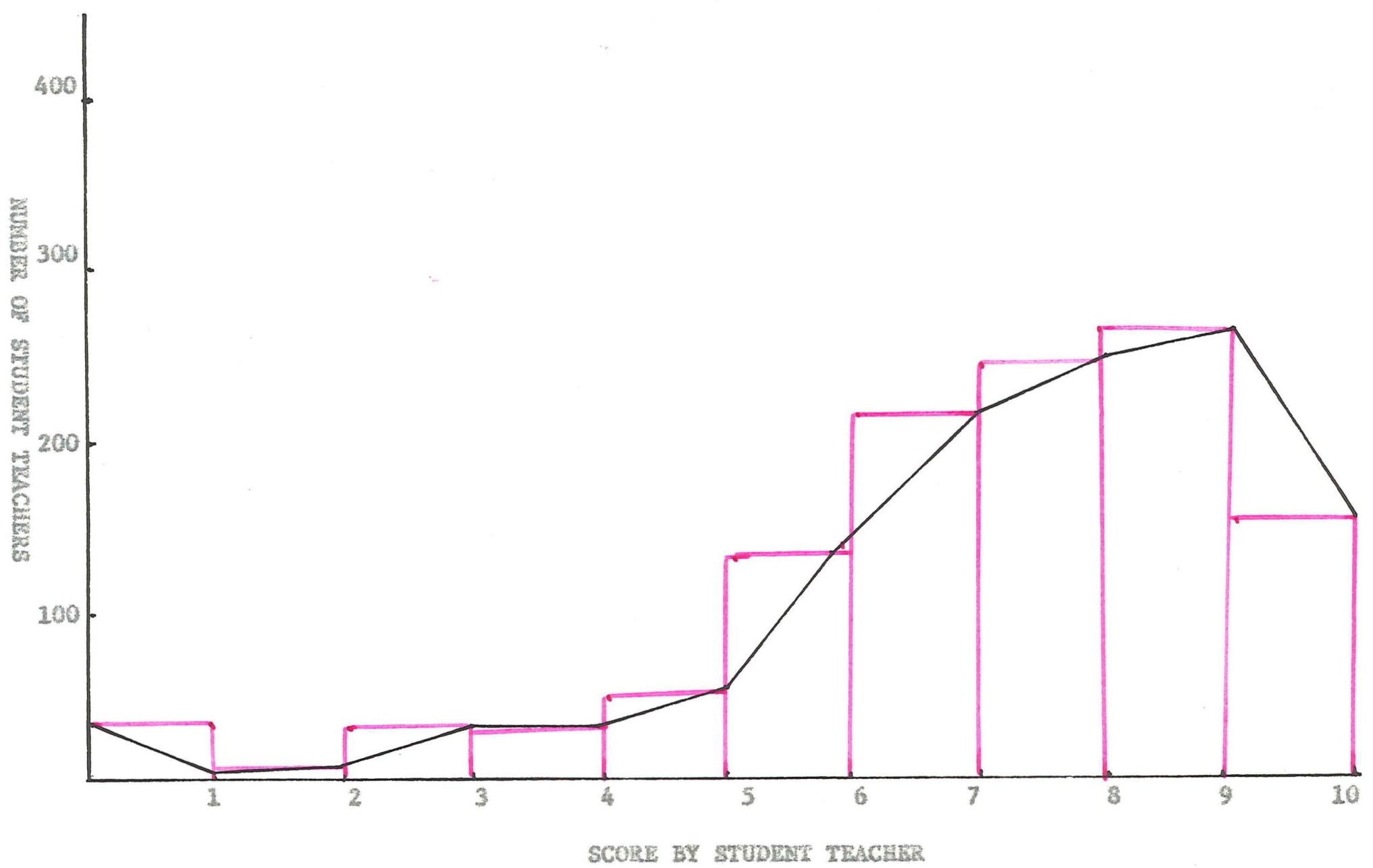

F1gure 6: Prequency distribution for teaching ability score. 


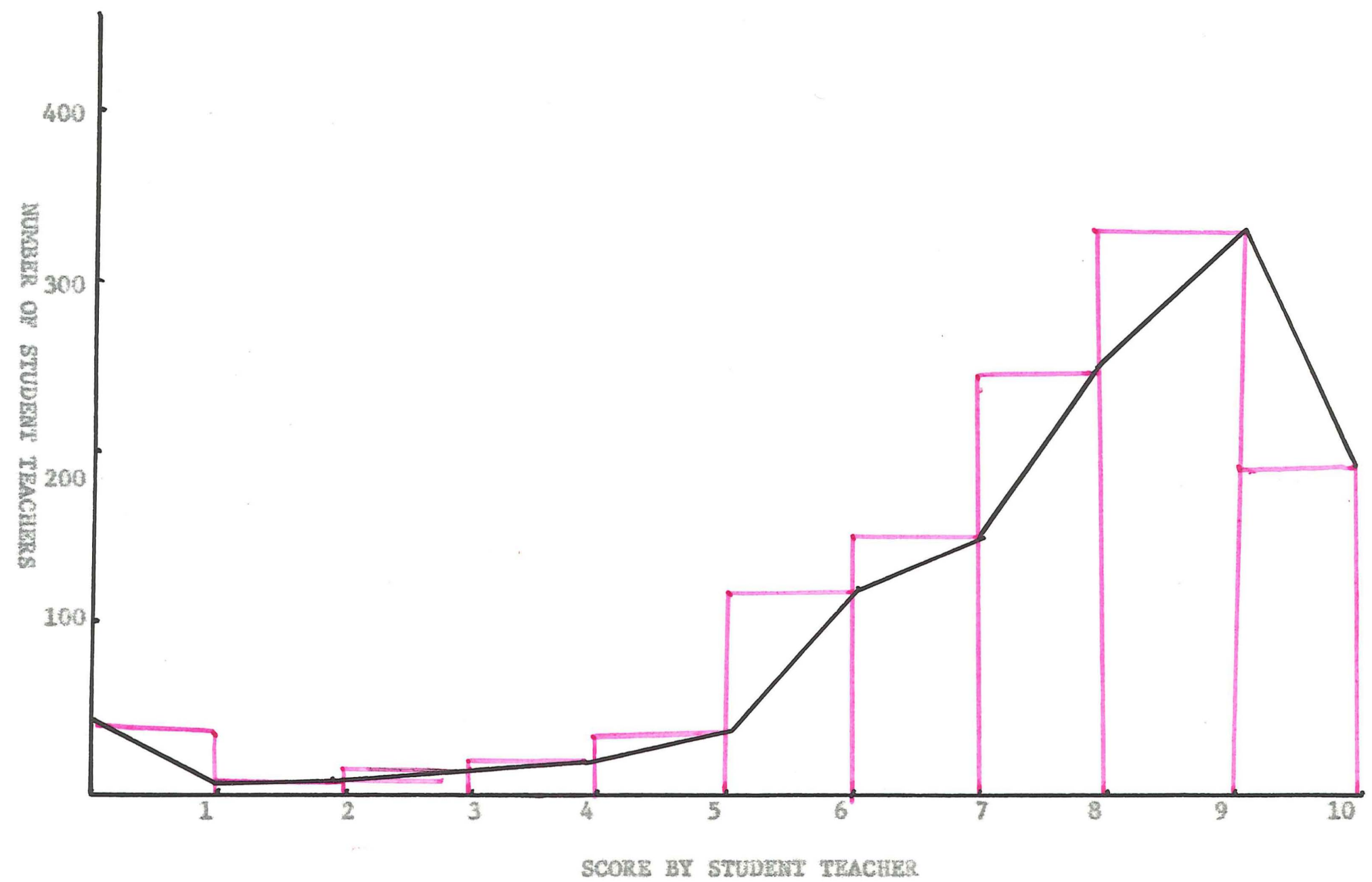

There 7: Frequency distribution for ablitty to get along score.

Black Ine represens trend. 


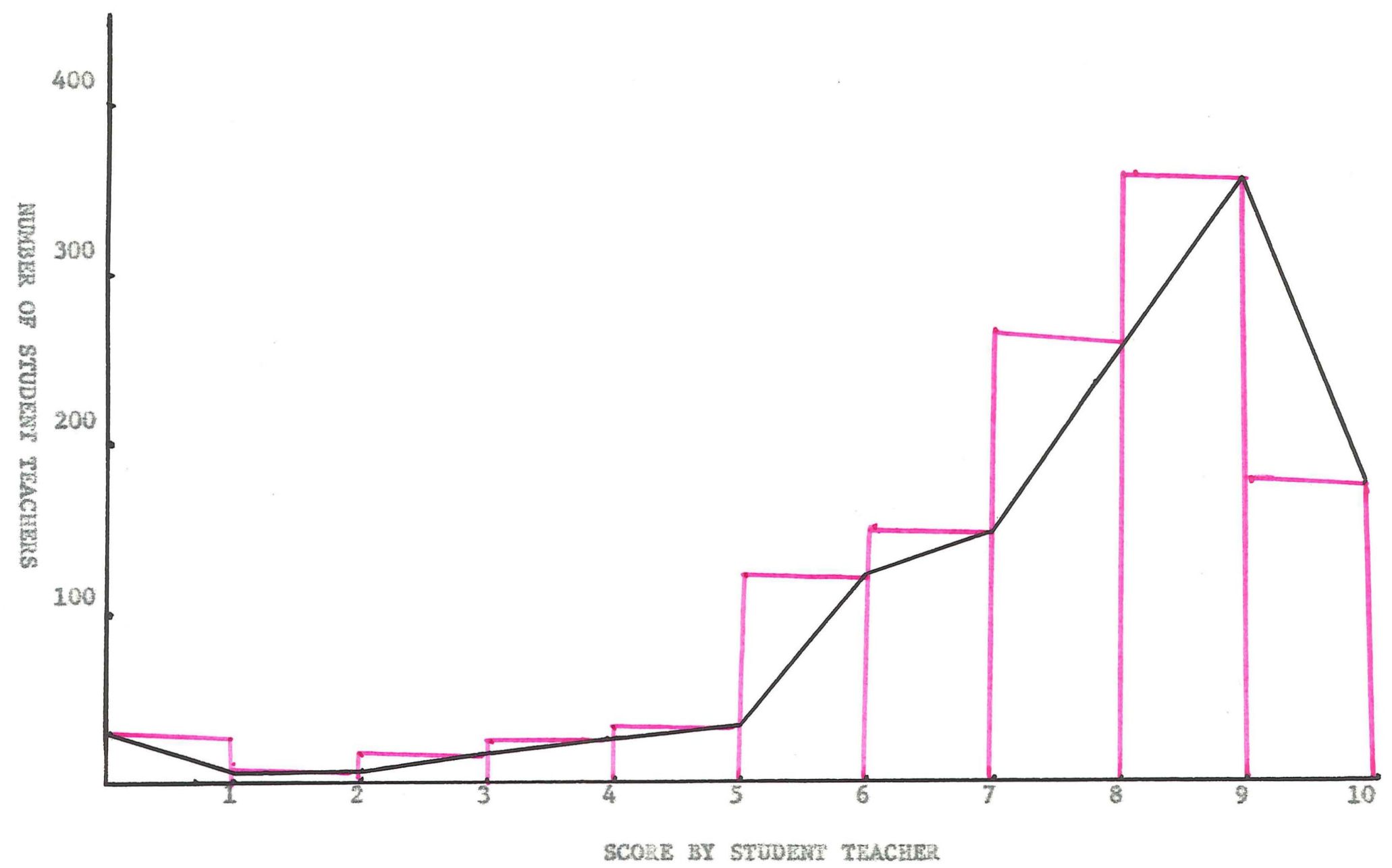

Yigure 8: Frequency distribution for professlonal attitude score. Black line represents trend. 


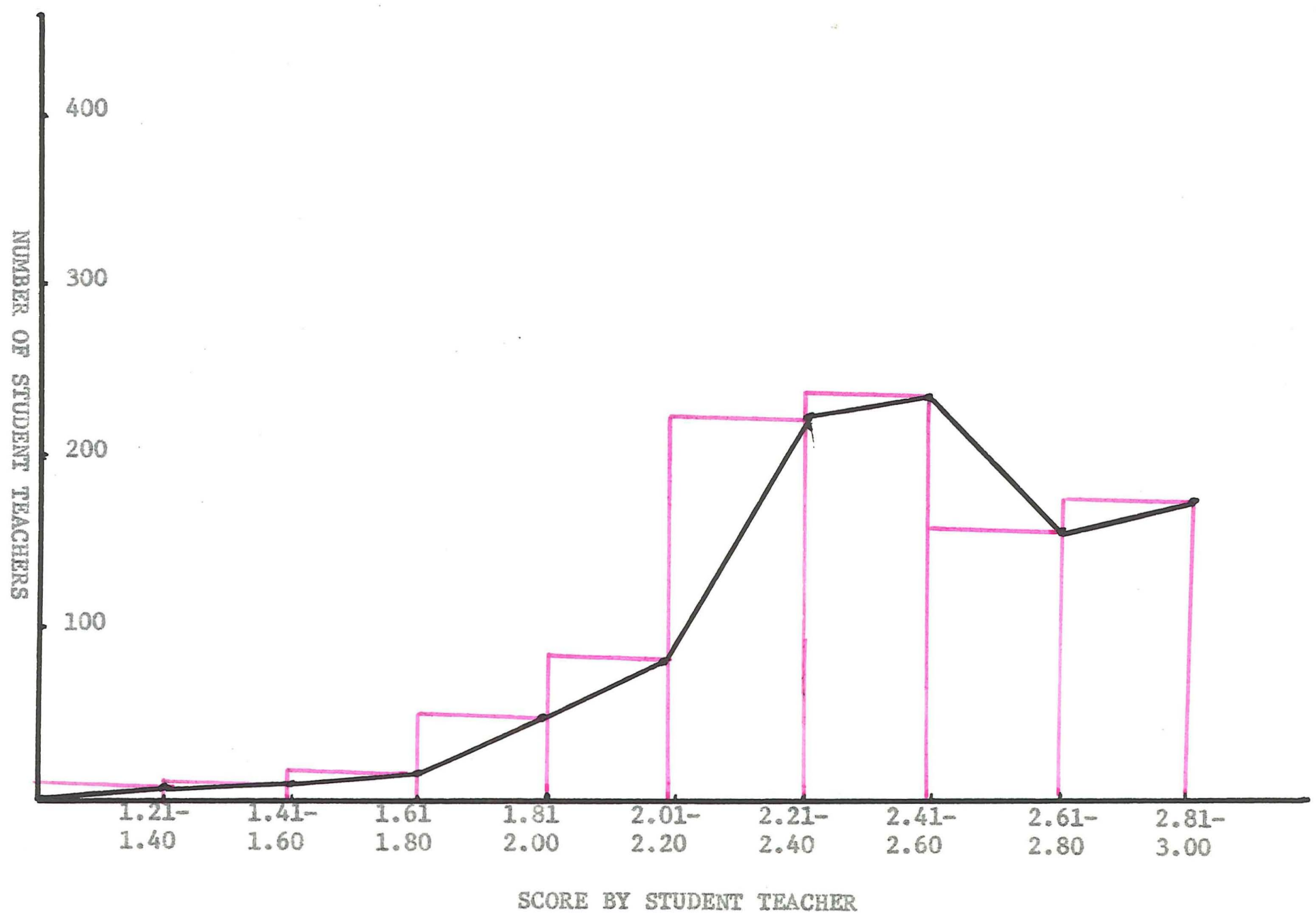

Figure 9: Frequency distribution for interview score.

Black line represents trend. 


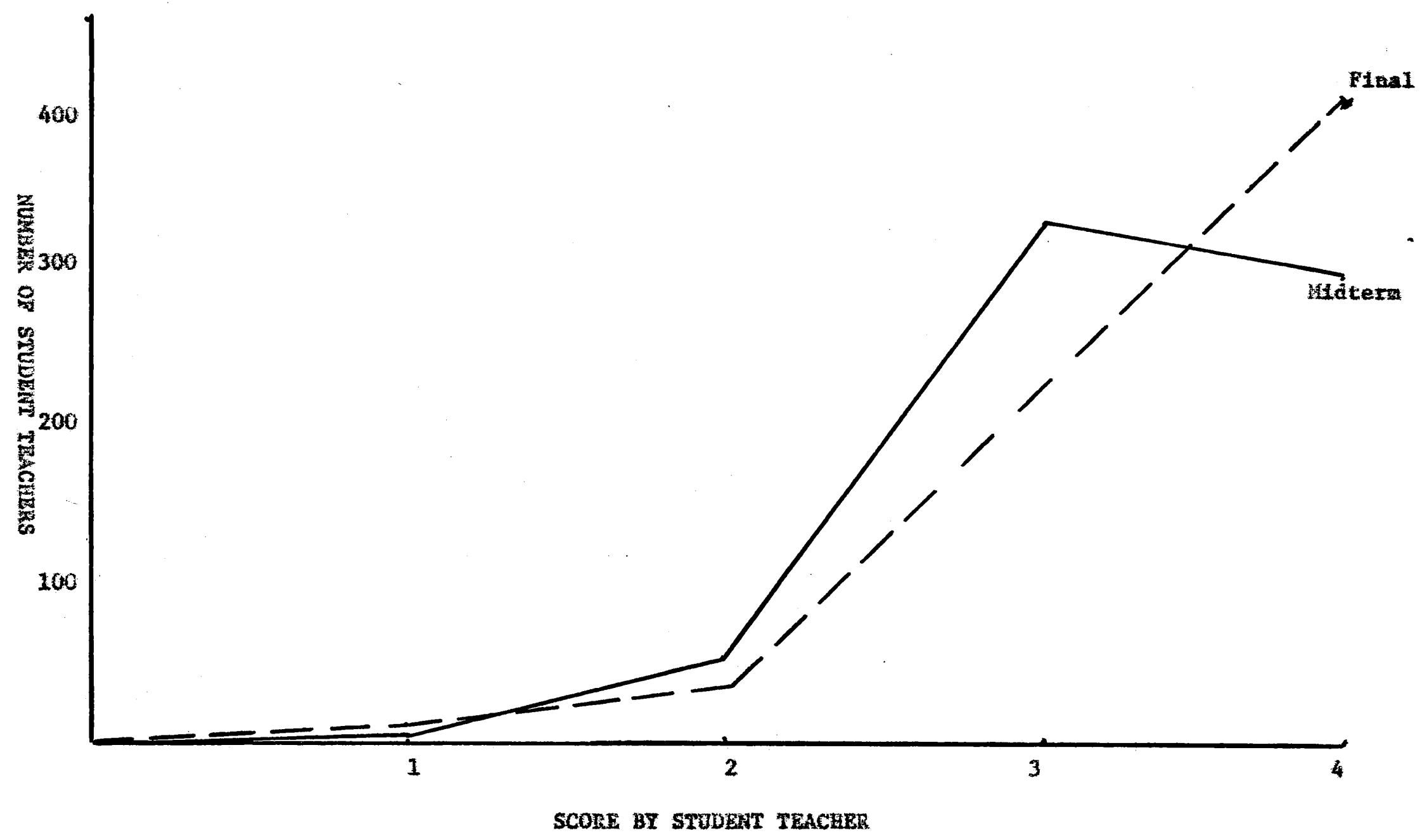

P1gure 10: Prequency distribution for aldterm and final school evaluation score. 
Table XIII shows the fIndings for the rematning Itens used in Phase II of the data design.

TABLE XIII

STANDARD BEVIATION, QUARTILE RANGLS, QUARTILE

DEVIATIOW, AND COEFRICIENT OF SKEWMESS FOR

ITEHS $1 B, 5,6$, and 7 OR THE DATA SHEET

\begin{tabular}{|c|c|c|c|c|c|c|}
\hline NAME & S.D. & $\mathbf{q}$ & $Q 2$ & $Q 3$ & $Q D$ & C. $\$ \mathrm{sk}$ \\
\hline $\begin{array}{l}\text { Area Grade Polnt } \\
\text { Average }\end{array}$ & .6322 & 2.488 & 2.797 & 3.076 & .294 & -.427 \\
\hline $\begin{array}{l}\text { Profeestonal Grad } \\
\text { Point Average }\end{array}$ & de 6508 & 2.776 & 3.028 & 3.432 & .328 & .115 \\
\hline $\begin{array}{l}\text { Cumulative Grade } \\
\text { Point Average }\end{array}$ & .5842 & 2.473 & 2.784 & 3.044 & .287 & -.370 \\
\hline PInal Evaluation & 1.484 & 6.969 & 8.256 & 8.809 & .920 & -.857 \\
\hline Interview & .3178 & 2.347 & 2.479 & 2.735 & .194 &.- .142 \\
\hline
\end{tabular}

PHASE III

Phase III consigted of correlating the following ftems:

1. The area grade polnt average.

2. The profeselonal grade point average.

3. The cumulative grade polnt average.

4. The final evaluation acore.

5. The interview acore.

Table XIV Includes correlation matrix of these 1tum, Also Included in Phase III were correlations of selected samples of scores 
on the Interview and Inal evaluation form. This was done to see if the Intorview correlated with success in student teaching on a high10w basis.

TABLE XIV

CORRBLATION RATRIX POR ITHSTS

USXD IN PHASE II OF

DATA DESIGA

\begin{tabular}{|c|c|c|c|c|}
\hline $\begin{array}{l}\text { ARAA } \\
\text { GRA }\end{array}$ & $\begin{array}{l}\text { PROF } \\
\text { GPA }\end{array}$ & $\begin{array}{l}\operatorname{Cos} \\
\mathrm{GPA}\end{array}$ & $\begin{array}{c}\text { PINAL } \\
\text { EVALUATION }\end{array}$ & INTERVIEK \\
\hline 1.000 & 0.2643 & 0.1805 & -0.0156 & 0.0045 \\
\hline 0.2643 & 1.000 & 0.5873 & 0.0797 & 0.1863 \\
\hline 0.1805 & 0.5873 & 1.000 & 0.1173 & 0.2080 \\
\hline-0.0156 & 0.0797 & 0.1173 & 1.0000 & 0.0646 \\
\hline 0.0045 & 0.1863 & 0.2080 & 0.0646 & 1.0000 \\
\hline
\end{tabular}

PHASE IV

The purpose of this phase of the date design was to interpret the flndings. Chapter IV does this and alwo Includes the reconmendations and conclusions. Since this is the case no explanation of the findings of Phase IV of the data design will be given In this chapter. 
CLAPTEX IV

INTERPRETATION OE THE PINDTHCS

This chaptex w11 be divided Into bix sections. The sections wi11 how the analysis and findinge in relationship to ach of the six hypotheses that wore otated In Chapter I. Along with the findings w111 be the conclustone made from the findings about aach of the hypotheses. Chapter $V$ w111 include the recomendaclons that reaulted from the concluolons drawn in this chapter.

THE FINDINGS ON AXPOTHESIS I

This hypothesis stated that the Interview comittee's evaluation of the student taaching candidate had high correlation with the tudent teacher's score In atudent teaching.

To test this hypothesis the total group of scores vere correlated rather than a random sample. The reault: indicated a correLetion between the Interview and the fInal eveluation scora of .0646 . Th1e is a low correlation and it Indlentes that there 18 no ofgnificant correlation between the two variables.

The coefflclent of akewness for both varlables ind1catad a skewnese to the left. The Interview score coefficlent of skeness was equal to -.142 and the final evaluation score coefficient of skamess was equal to -.857 . Th1s Indicated that both distributions 
were skewed in the same direction and that this was a comon characteristic for both distributions.

The quart11e deviation of .194 , for the intervien, and .920 for the final avaluation, Indicated that both varlable were sfmilar In this characteriatic. The atandard deviation of 1.484 for the final evaluation, was greater than the .3178 for the interview. Th1 was also true for the quartile deviation and coefficients of akevness. An explanation for this 1 that the range for the interview of 0-3 was 1gniflcantly sualler than the 1-10 range for the final evaluntion, Thls nould account for these differences. Both d1stributions had the ame characteristics. Thus, if the two vartables vere compared to normal curve there would bo a rasulting abnormally high number of high ratings. This indicate general reluctance on the part of the Intervlewers and the student teaching aupervibors to give low scores. In order for a student teacher to be Wthin the average quartile on the final evaluation he mut score at leat: 6.348 on the final evaluation. With the range of scores from 1 to 10 on the final evaluation it would ean that the 6.348 score. which is equivalent to the lowest score in the second quartile, is algniflcantly different then what would be the acore for the sacond quartile, if the niddle score on the range of cores of $\mathrm{S}$, was actually the widdle score In the distribution. To obtein the same results in the Interviaw a student must score least 2.1615 . Agatn with the range of 0 to 3 , the midpoint should be $1.5,1$ this were nomal diatribution.

The concluelons appear to be conclueive. There is no evidence 
to aupport algnificant correlation between the interview score and the flnal evaluation acora. This would mean that atudent's acore in the Interview cannot be Indeative of his success in student teaching. The sample of 868 cases supplies an adequete crose-nection to aubstantiate this concluslon.

Since there was no evidence to support any correlation in this area 1t was suspected that posaibly there could be corralation between the Intarviow and the final evaluation for student teachers on either end of tha distribution. To test this posstbility a product woment correlation was run on two sumple groups. The first sample Included 118 cases. Wach case that was selected showed a score somewhere batween 1.81 and 2,40 on the interview. The asaumtion was that this score on the Interview should indicate a corresponding score in student teaching. The evidence Indicated a correlation coefficient of -.1037 . This again is not a eignificant correlation level. The conclusion is that the student who has scored 10w on the Interview 1. not necessarily going to core low in student teaching. An explanation for this 1 that the abilitias rated in the interviev do not correlate with the skl11s and abilitles needed to succesefully student teach.

Table XV ohows the computation made to test this assumetion. 
TAB $X v$

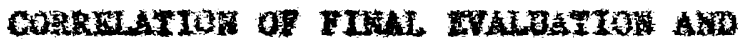

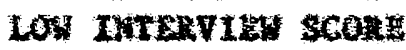

\begin{tabular}{|c|c|c|c|c|c|c|c|c|c|c|c|c|c|c|}
\hline$S^{5}$ & & & & & 2.00 & 3.00 & 4.00 & 5.00 & 6.00 & 7.00 & 8.00 & 9.00 & 10. & $\operatorname{lotal} d x^{t} d y$ \\
\hline $\begin{array}{r}18 \\
\end{array}$ & & & & & 1.625 & 2.625 & 3.625 & 4.625 & 5.625 & 6.625 & 7.625 & 6.625 & 9.625 & \\
\hline & $\begin{array}{l}3 \\
d\end{array}$ & & & & 0 & 1 & 2 & 3 & 4 & 5 & 6 & 7 & $B$ & \\
\hline & & 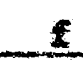 & & & a & 1 & 4 & 3. & 7 & 19 & 27 & 43 & 14 & 118 \\
\hline & & & 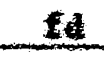 & & 0 & 1 & 8 & 9 & 28 & 95 & 162 & 301 & 112 & 716 \\
\hline & & & & $\mathrm{Ld}^{2}$ & 0 & 1 & 16 & 27 & 112 & 275 & 972 & 2107 & 396 & 4606 \\
\hline $2.40 \quad 2.305$ & 3 & 23 & 115 & 575 & & & 10 & 40 & 75 & 120 & 245 & 240 & & 7330 \\
\hline 2.20 .2 .105 & 4 & 80 & 320 & $12 \operatorname{sen}$ & & 4 & 16 & 24 & 80 & 260 & 528 & 840 & 160 & 1912 \\
\hline 2.001 .905 & 3 & 15 & 45 & 133 & & & 6 & 3 & & 45 & 6 & 126 & 72 & 258 \\
\hline Total & & 118 & 480 & 1990 & & & & & & & & & & 2900 \\
\hline
\end{tabular}

$I=-.1037$ 
The sccond sample was bected to test tha assumption that a low score on student teaching hould correlate with a low score on the 1nierview. All cases were selected in the same ample with a scora becween 1.25 and 6.00 on the final evaluatlon forth. This resulted in a sample of 99 cases. These 99 cases and thelr scores were corralated with the correaponding score on the Interview. Table IVI shows the computation made to test thts assumption. 
TABLE XVI

CORRELATION DF LOW FTNAT.

GVALUATION SCORE AHD

INTERVIEW

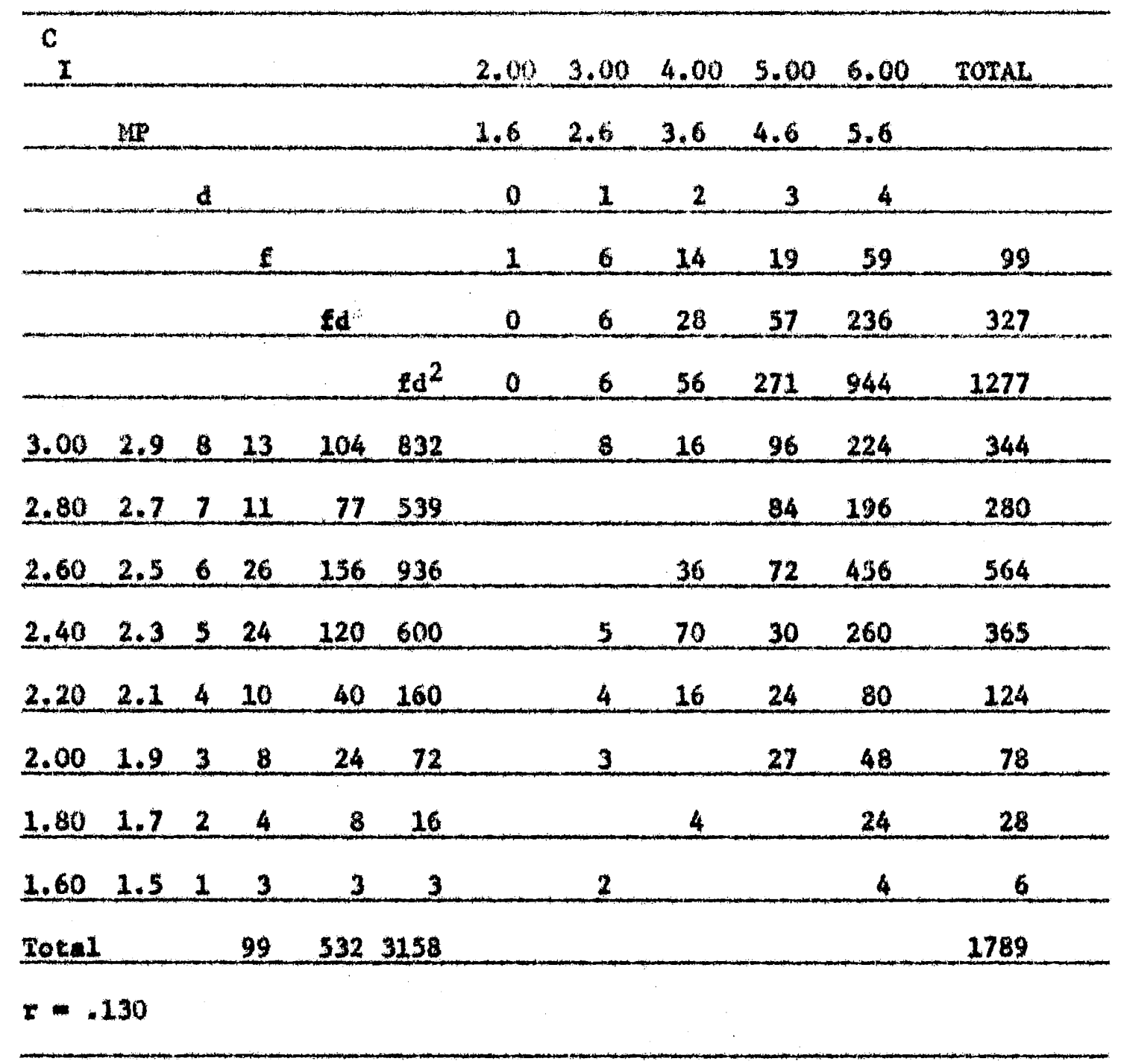

The correlation coeffictent of .130 indicated thare was no mignficent correlation to support this assumption.

In summary, there is no evidence to support the hypothesis. Rather, there semas to be signiflcant lack of evidence. Thts would Indicate that posalble danger could exlst if the Interviaw scora was 
used to predict how atuitent was golng to score la his student teachIng exper1ence.

There is also no evidence to support the posteton that the interview can Indicate a student tho will score low or high in student teaching.

\section{FINDINGS ON HYPOTHESIS II}

This hypothesis atated that the interview conaltted rating of the student teacher 18 a better predictor than the gtudent's grade polnt average in indicating his probable success in atudent teaching. The evidence Indicates that th1s hyothes cannot be statistically supportad in all areas.

The correlation coefficient between the interview and the acore In tudent teaching was .0646 , whereas, the correlation coefficient between the cumilative grade point average and the otudent teaching score way .5873. The correlation coefficient between the profedsional grade point average and the student teaching ecore was .0797 , which is higher than the .0646 intervien final evaluation correlation. An axception to this to the are grade point average and the otudent teaching score comrelation of -.0156 , which 18 lowar than the intexviow correlation of .0646 . Based on tini evidence the cumulative grade polnt average and the professlonal grade point avarage have higher corralation wh the otudent teaching score than does the intarview. The area grade point avarage doas not. It should be noted that the only signiflcant differences would be between the cunulative grade point avarage and the interview. 
The conclueton would be that the cumulative grade polnt average does have a slgniflcantly higher correlation with the student teaching acore than does the Interviev. The aignificance of the cunulative grade point average as a predlctor of success in atudent teaching is at111 questlonable ag the .5873 correlation coeffictent 1. att1l not satiotically lgnificant. The interview does not have a signfleantly higher or lower correlation with the score in student teaching than do the area grade point average and/or the profesatonal grade point avarage.

\section{FINDINGS ON LFROTUESIS III}

This hypothesis atated that the reason for fallure in otudent terching was of a non-acalenic nature. The fladiags indicated that 37 tudents had atther falled student teaching or been given an exteaded axpertence in student teaching. The cauges for efther the fallure or extended expertence were found to be:

1. Could not control elass. 14

2. Could not comunicate 9

3. Hed no self-confidence 7

4. Could not relate to students. 3

5. DId not know aubject watter 2

6. Fandly preamures 1

7. Was unrealistic. 1

The conclualon would be that the jortty of fallures in student tenching are due to factors of a non-academic nature. Thls conclusion 1s conglstent with another otudy that was carried out on national 
baste in 1966-67 by Dr. James A. Johnson. 10 the findings of this study indicated that the wajor reasons for fallure of atudent taachIng were:

1. Inablity to control otudents.

2. Unwllingness to work.

3. Poor knowledge of teaching wethodology.

4. Inability to get along with other teachers.

5. Poor subject matter background.

6. other.

FINDINGS OF HYPOTHESIS IV AND HYPOTHESIS V

Investigation of the data revealed that the rajority of deflclencies were low grade point avarage scores by students. Since this was the case, Hypothesis IV and Hypothesis $v$ were combined. The bypothesis tested was that students, who were adratted to student teaching with deflctencles, did not score afgnificantly less than noxmally admited studento.

To test the hypothesis the students with deflelencles were 1dentifled. Their scores vere totaled and a mean was computed. Th1. sample consisted of 123 cases. The means of this group were compared to means for the total sample and the reaulta are shown In Table XVI, The assumption made in the hypothesis ls that a student, who was ainfted to student teaching wh a deficlency, should score lower in student teaching than a regular student. The findings indicated that In three ardas on the final evaluation score the mean for the 
TABLE XVII

COARARXW MUANS FOR DEFICIRUCY GROUP AND

THE TOTAL SAMPLE

\begin{tabular}{|c|c|c|}
\hline CATBGORY & DEFICIENCX GROUP & TOXAL GROUP \\
\hline Subject Kattar & 7.35 & 7.56 \\
\hline Teachlng Ab1lity & 7.46 & 7.41 \\
\hline Abillty to Get Along & 7.93 & 7.82 \\
\hline Professional Attitude & 7.90 & 7.77 \\
\hline Plnal Evaluation Average & 7.44 & 7.83 \\
\hline School Midtem Evaluation & 3.41 & 3.32 \\
\hline Sehool Pinal Evaluation & 3.55 & 3.44 \\
\hline
\end{tabular}

defletency group was above that of the regular group. In the other area on the final eveluation fora the score of the deficiency group was at least withn one standexd deviation of the mean of the total sample. This was also the case for the wean of both groups on the core achieved on tile final evaluation form. Since the means of the daftctency group are elther bove or wthin one tandard devtacton of the means of the total cample in all of the categortes, there is no agnificant difference in the level of the scores.

On the echool aldterm and final evaluation form the deficlency group had a mean score which wa higher than that achieved by the total Broup.

The conclueton drawn is that there is no afgoificant difference In the cores achleved by scudents with deflatanclat and regular 
atudent.

PINDIACS OU arPothesIs VI

This hypothesis was changed to ont a diviaton between elementery and secondary mafors in education. This was done to $11 \mathrm{mlt}$ the atatiotical andysis necessary by delating this division.

The fludings on this nypothesis failed to relate to the directionel dealgn of this gtudy. The study did indicate that of the thrae areas of the grade point average, which was a consfleration In this hypothesis, the cumulative grade point average had the highest correlation with the score achieved in student teaching. 
CUAPIE⿰冫欠

RECOMABNDATIOAS

The teate done on each of the hypotheses used in this otudy have provided Information from which these recomendatione are made. These recomendations should assiot the School of Education In dealIng with wost of the 1saue IIsted in Chapter I.

\section{HXYTHEsTS I}

In ragard to Hypothesis $I$, a high Intervlew score did not correlate with a high score in student taaching. The reverse was eleo true, In that, a low Interview score did not correlate with a 10w core in tudent tenching. As the conclusion in Chapter IV otated, the atudent's Interview score did not correlate at any atatiatically algnifleant leve1, with the student's ocore in atudent tuaching. This lack of ovidence is valuable in that it forms the basts for these recomendation:

1. That a student"s score in the Interview not be grounds Lor denylng hin admialon into atudent teaching.

2. That a sudent's score In the Interview not be used to predict how the student might achleve in student teaching.

3. That what the Interviev purport to 1dentify in each candidata be looked at critically. A revamping of the qualities and charecterfsties rated in the Interview could 
produce an Instrument that would correlate with a student' score in student teachtng.

4. That the intervlew should be examined carefully as 1ts role In the screaling of student taachers is MIghy questionable.

5. That ench atudeat should not be required to eake the interviev"

6. That furtheresearch be conducted to Idantify those behaviora and characteristics a student ahould exhlbit to Indicate that he will be succassful in student teaching.

\section{HXPOTHESIS II}

With regard to Hypothesla II, a sinllar lack of statiatically supportable evidence was found. The Interview has already been stated a unraliable in predicting how student should score in student teaching. Stnilat statements can be made about the graid point avarage prexequisitos used to screen student teachers. The area, and profeastonsl grade polnt averages did not correlate with any degree of signiflcance. The cumulative grade polnt avarage correlated higher; however, it did not correlate at a level where any statiatical rellablifty could be placed on 1t. Since there is no apparent correlation the recommendation are that:

1. The grade polnt average not be used in tha ereening of student teachers.

2. That a atudent be allowed to student teach, unlese his cumulative grade point average is below that raquired to wintain his enrollaent at Portland state Univeraity. 
HYPONHESIS III

Regarding Fypothesis III, the conclusion atated in Chapter IV was that the jority of students, 94 percent at Portland State Valveralty, fall atudent teachlng because of difficulties other than a lack of subject matter background. The racommendationa are that:

1. Additional requirementa be inserted into the School of Education's pre-atudent ceaching program that are of a communication nature, e.8., Interpersonal Relationship Training, Group Dynamice.

2. That the supervisory staff used to supervise etudent teachers not be celacted on subject matter proficlency alone. Rather, that the supervisor be able to use comantcation skills and have in hle background sowe communication training that he can transfer to his student teachers.

\section{HYPOTUESIS IV AND HYPOTHESIS $V$}

In regard to Hypothea1: IV, and Hypothesia $V$, no racomendations are made, since it has been previously recomended that the interviev and grade point average clearance be daleted as acreening Instruments for student teaching.

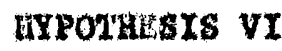

In regard to Hypothesis VI, no recomendations ara made, since 1t has been prevlouely recomended that the grade point averages be deltad an screening Inetruments for student teachlng. 
An additionel recomendation is that the student teaching phase of the School of UducatLon's program be subject to open enrollmont. This result frow the fact that thete is no evidence to aupport any correlation between prasent acreening proceduras and success In student taaching. It is also recomended that an interview be hald with ench candidate when he appliar for aduigsion to gtudent teaching. This Interview ahould be held for the following purposes:

1. To secure Informetion, about the applicant, that w11 ald In placine hin with cleseroom teacher, and supervisor. The atudent teachet should be placed in altuation that 1s consiatent as posstible wh his philosophy of education and Iffe syle.

2. To ascertein 1f the applicant has any outward psychological or behevioral diffeulties that could affect his performance In the clasaroom. Yosstble examples could be apech problen, or extrome èratic uehavior.

One purpose of thls peper was to provide data with which the School of Education could address those lssues lioted in Chaptor I. Sow possible application of this researeh and 1 to Ilndiage to these 16aues ara:

1. That to wintain the one to aixteen student teachergupurvisor ratio; the School of Education might amploy as wany supervibors as necesanry. This number to be determined 
by enroliment.

2. That the School of Dducation develop a research program designed to produce date as to how many student teachers a supervigor can effectively work with under a variety of conditions, e.g., Clinical Profeesor Program, a program with more responstbilty for supervision placed on the clessroom teacher, a program with the UnIversity Supervion's role nore advisory than superviaory.

3. That due to lack of reliable measures to determine how atudents 111 succeed in atudent teaching, no limits be placed on etudent teaching enrolinent. To meet the Incressed $\mathrm{FTh}^{11}$ required the best avallabla route is to increase the student teacher-supervisor ratio. The elusterIng of etudent teachers and the development of sudent teaching centere would olfuinate the time currontly apent by suparvisor: in travel between schools.

4. That 1 if Intts are neceseny they be imposed at the Admisaton to Frogram atage, and not upon the student's application into studont teachtng.

5. That in using preaent measures for screning there appears to be no way the School of Rducation can accurately screen student teachere. Resesrch is needed to determine what data can be used to accurately prodict a student's probabl11ty of auccess in student teaching.

The last recomendations ade in this study are that: 
1. Further research is neded into the aro of whic a student teacier does and how those dharacteristica can be measured.

2. These findings be correlated with the atudent" prestudent tachñ qualifications, e.g., grade point averages, buhavior patterns, contunfeation ablitties. The results would yleld tate with wich the school of Education could 11mit its enrolinent in student teaching.

\section{CONCLUSTON}

Thls study has only penetrated the area opened by the data gathered in this des1gn. Numerous opln-offs have been mentionad in the sudy an being ways in wheh this data could be used for further research. This study las slmply openad the door. It is hoped that 1t may help lead to bettar ways and means of loproving the education providad to our chlldrat by linproving the quality of the taacher in the classroom. 


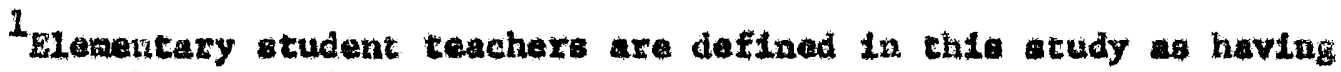
student taught in grades one to 1x. Any other grade level 10 con-iderad as secondary in this study.

${ }^{2}$ Jane: A. Johnson. A National Survey of Student Meaching Erontame (Baltimore: Mult1-8tate Teacher Education Project, 1968), p. 19.

${ }^{3}$ W1th1n this study the term grade polnt ayerage, unless otherwee apecifled will refor to the atudent' grade point average in three areas:

a. Cumulative grade point average is the pumerical average for all of the atudent's college work.

b. Professional grade point average is the numerical average of the student's grades in all profeselonal couraes taken prior to student teaching (Appendix A, page 4).

c. Aran of concentration grade polnt average is the numerteal average achlaved by the studeat in the acadento areas that make up his area or areas of concentration. Two areas of concentration are requited for elesentary majors. One area of concontration is required for secondary majors.

4 A numerical score was computed from the flnel evaluation form. * low score we determined from the quartile davintione. Thus score fell wichin the range frow zero to $81 x$ on the flual avaluation form.

Shese otudente are admitted to the student teaching progran by patitioning the selection and Retention Comittee. If this comictee approves tho student's application he is given walver and allowed to tudent teach.

6 Comion deflelences other than $10 \mathrm{w}$ grade point averages are: subetitution of courses for required courses, studente did not complete all the prerequistes prior to applying for admission to student teachIng. and fallure of the student to complete a mathods course prior to atudent teaching.

$7_{A}$ high score 1 s defined 38 falling between eight and ten on the final evaluation scare. 


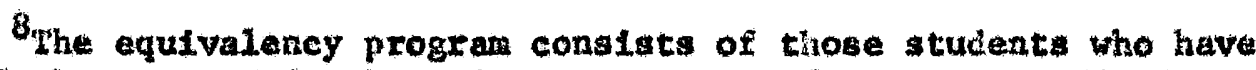
already been ewarded a becalaureate degree from an accredited institution prior to their applying for tudent teaching.

9 Thls category is interpreted in two different ways by most supervisors. Some otudente are rated on their ability to do menagerial taske in the classroom. Other studente are rated on thetr knowledge of thodology.

10 James A. Johnoon, A Mational Survey of Student Teaching Programs, (Baltimore: Multi-state Teacher Education Project, 1968), p. 52.

11 Full Time Equivalent (FTE) 1s the terainology used to definc a faculty nember's time. If a faculty meraber's job description include. .50 FTE responsiblilty to aupervision, he would spend 50 perent of ais time in superviston. FTB is aloo used to deternine departmantal salary costs. If the offlee of Supervised Teaching has been allocated $14.5 \mathrm{FTE}$ for superviston, this would wean a total of 14.5 FTR in faculty time could be used for supervision. 
Arkin, Herbert and Rayniond R. Cotton. Statistlcal Mathods. Barnes and Hoble, Inc., Wew York, 1968.

Ark1n, llerbert and Raymond R. Cotton. Tables for Statisticina. Barnes and Noble, Inc. New York, 1950.

Directlong for Completing Appllcation for Student reaching or Internghip. Portland State University, 1969. (School of Education publication).

Paculty Handbook. Portland State Univers1ty. 1969.

Inforantion and D1rections for Completing Appl1eat1on Lor Adm1sefon to Program of Studies in Teacher Bducation, Blententary Application. Portland State Univeralty, Decenber 11, 1969. (School of Education publication).

Information and Directione for Completing Application for Admission to Program of Studies in feacher gducation, Secondary Appifcation. Portland State Unfvereity, September 2, 1969. (school of Education publication)

Johnson, Jame A. A Naclonal Survey of Student Teaching Proxrams. Nult1-State Yeacher Education Projact. Baitimore, Maryland, 1968.

Portland State University Bulletin, Undergraduate Gatalog Iseve. Portland State University. Karch, 1969.

Schooler, V1rgil E. A Survez of the orgenization and Administration of Student Teaching in Salected Teacher Gducation Institutions. Indiane Untvera1ty, 1965. 
APPETDIS A

\section{DLEMENTARY APELICATION}

IWFORMATON AND DIRECTIONS FOR COMPLETINO APPLICATION FOR ADUISSION TO PROGRAM OF STUDIES IN TEACHER EDUCATION

A11 dudents who wiah to secure teacining credential or graduate frow a Portland state Univarstey Brogran of Teacher Bducation must apply for admision to the School of llucation before proceding with profess lonal courgeg. Adminsion is contingent on the following prorequisites.

1. Adutesion to Portland State Unfverstty.

2. Completion of 75 quarter hours of college course work including 15 quarter hours at Portland state University with a mintaun 2.50 cumulative gpa.

3. Completion of the attached application form Ineluding the required number of hours in subject mattex areas as 11sted on page one.

4. Completion of a planned program of tudiea with an adviaer. students in elementary educstlon ar advised at the Advisement Center (262 or 263 old Ma1n).

5. Subnission of valid TB chest $x$-ray or tine teat with this complated application.

Adafiation to the progran of atudies in teacher education is subject to the approval of the Teacher Education selection and Retention Comattee. Student approved for admiselon w111 be malled an admision card. This card mast be presented at registration each term in order to enroll in profesgional courses.

Undar unusual clrcumstances walvers may be losuad by the Dean of the school of Iducation which give temporary perminsion to take professtomal courees. These valvers sre not given until aftex the first day of registration and unles thare is evidence to indicate that every effort is bolng made to moet adingafon requirements at the ear110st posatble date. 
A separate application for admisaton to studeat teaching can be obtalaed In the offlce of supervined Teaching (201 01d hatn). Th1s application nust be conpleted and turned in before the deadilne date which is the flrst Friday of the reqular academic term proceding the term of tudent teacing, (fall term student taaching applicants muxt file by the end of the flrst woelk of spring term).

$11 / 13 / 69$ 
APPLICATION FOR ADMISSION TO TWU PROGRAN OF STUDIES IN TEACHER LDUCATION

Date: Llenentary (1)

I.D. No. Juntor

(1) (2)

Dace adratted to (esv) Sentor High Taaching Flald (s) Teaching $1 \mathrm{held}$

3it.

Virs. Has (Flret) (Mdde) (Last) Date of birth:

Actress:

$$
\text { (Street) (C1ty, State, 21p Code }
$$

Other Colleges Attended:

College Datea

College Datas

Do you hold a degree? Yee. Ho If yes, what degre? Year

Wame of Institution granting degree Major

Quarter hours of college vork completed? Cumulative GRA at this Quarter hours completed at PSU_Cumulative GPA at PSU?

Have you aver been convicted of cxime other than a notnor traffic violation? Yes No If Ie , attach full particulars on beparate sheet.

Have you a phyelcal deflcteney which would limit ongaging in normal teaching activitles? Yos No If yes, explain on separate oheet or sec Coordinator of Supervised Tenching.

Have you been under constat nedication and/or treakment for any long period of timet Yes No. If yes, explain on separate sheet ix see Coordinator of Supervised Teaching.

Are you now or have you been under pisychlatric treatment? Yes wo If yes. explatn on separate sheat ox see Coordinator of supervided reach1ng.

Indicate below the nubber of guarcer hours that you have comoleced auceesf fully in each of the following axeas: 
Required Completed

English Composteton

$3-6$

General Psychology

3

Uuman Developwent.

*speach

3

3

* Students who take no college Speech couraes will be requited to pass speech clearance tast (available only to graduate otudents).

signed

PERSONAL HISTORY FORW

Nane

Date

DIRECTIONS: Write a short autoblographical skech of your IIfe tellIng whare you grew up, schools attended, activities in school, hobbles, interesta, experiences with chlldren, when and why you chose teeching as a career and other things you think a professional educator might find of interat in considaring you as arospective teacher. This eccount is to be handuritten with pen and $1 \mathrm{nk}$. Check opeling, granmar, and general organiagtion because this w111 be read by many people. Additional sheets may be attached. 
BLGIEATARY

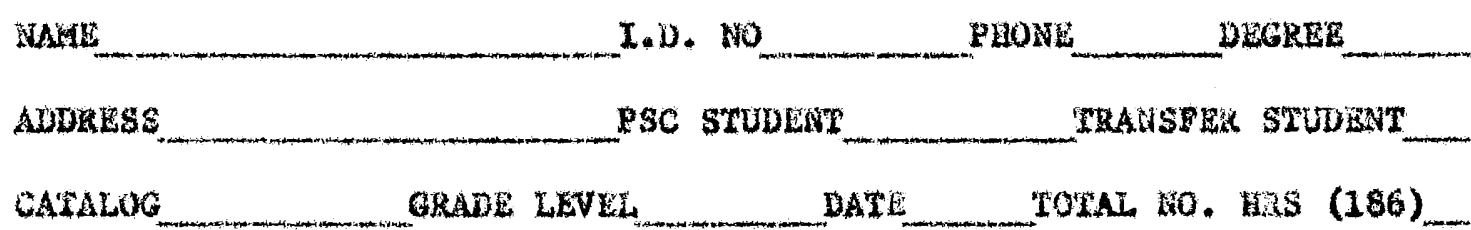

iNo UPPEX DIVISION HoUns (62)

\section{PROFYSETONAL BEQUIRUMETS ROR ALL STODENLS}

Fsy. 311 human Developmeat

* La 312 Ed Poychology

Lit 490 ch1ld. IIt, Lxb. Ijd 415 Studant Teaching IDd 407 tang. Arte Rdg. thd 440 philogophy of id.

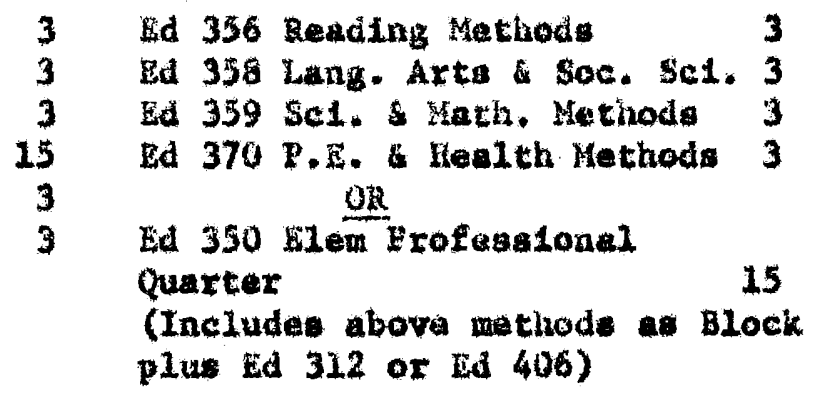

\section{GGWEAL REOUREMENTS ROR ALL STUDEATS}

REQUTRED HOUA IN SULBCT AREAS: Arte \& Lettere (18)

Soctal Sclence (18)

Sclence (both Blo. a Phys. Sc1.)

Hethematics (6)

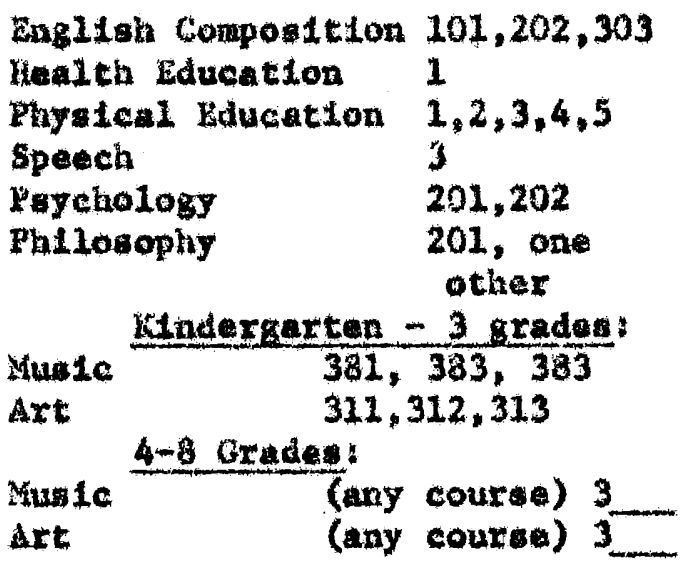

health Education 1

Paysteal Education $1,2,3,4,5$

Speech

Psychology

201,202

201, one

other

(18) 
30 Hours in one Divislon: (12 uppier diviston hours) Taken from: Forelgn Languages, ine Arts (art Music,) Sctunce, Health, P.E., Soctal Scionee, Language Arte, (Engllah, Fore1gn Languagea, Speect, and Theater Arts).

woris: Caken separately or wlth zo 350, To be taken after student Tancing; + Araes must not overlap.

Checked Through $\mathrm{F}$ Ss 19 Adviaox"s Ignaturat 
ARP LNDTX B

SECOHDARY APTLICATION

IWHORATIOH AWD DIRBCTIOHS YOR COWPLETIW APPLICATION FOR ADHISSIOA TO PRUGRAM OF STUDIES IH TEACXER EDUCATION

All students who wigh to secure a teaching eredential ot graduate from a Portlund State Unfvarsity Frogram of Teacher Educarton must apply for admiseion to the School of Education befora proceding with professional courseg. Adnission is contingent on the following prerequisites:

1. Adwedion to Portland State Univereity.

2. Completion of 75 quaxter houra of college course work including 15 quarter hours at Portland state Univarsity with a ninimum 2.50 cunulative spa.

3. Completion of the attached application form Including the required number of hours in subject matter arias as Liwted on page one.

4. Completion of alannad program of studies with an adviser. Students in accondary ducation are advised in tho acudemic department whlch offers thair teaching fleld (se pSU catalog for teaching (1)1dis and advions).

5. Submission of valid Ts cheet $x$-ray or tine tast with this completed application.

Admiaston to the program of cudide in teacher education is subject to the approval of the Teacher sucution selection and Retention Conmittee. Students approved for aduiagion will be salled an adnisaton card. Thls caxd wust be prenented at reglotration each term In ordar to enroll in profeselonal couraes.

Under unusual ciremotances walvera may be losued by the Dean of the School of Education which give temporary permission to take professlonal courses. These walvera are not given until after the firet day of regietration and unlese there 1s ovidence to indicate that 
every effort is being made to neet admisston requirements at the earliagt possible data.

A aeparate application for adrasion to student teaching can be obtalned in the offlce of Bupervised Teaching (201 01d Maln). This application must be cotplatad and turned in before tha deadilne dat which 19 the firat Friday of the rogular acaderte tern precedIng the term of student teaching, (fall terw tudent teaching applicants nust f11 by the and of the first weok of spting tern). $9-2-69$ 


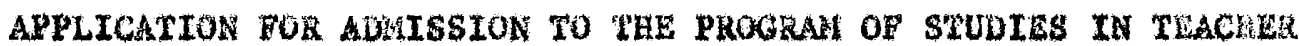
EDUCATIOW

Date:

Elementary (1)

I.D. Wo.

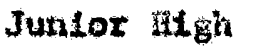
(1) Aresa of Concentration

Date Adteted to PSU Sentor Hgh Teaching Fiald(8) Teach Fiela

$\mathrm{Mr}$.

Htra. Date of b1rth:

Miss (F1ret) (MIdIe) (Lat)

Addrese:

$$
\text { (Struet) (CIty, State, 2ip Code) }
$$

(Phore)

Other Colleges Attended:

College Dates

Colleg* Dates

Do you hold a degrae? Yes liso If yes, what degree? Year hame of Institution granting degree Major Quarter hours of college work complated Cumulative GPA at this TIue? Qunter hours completed at RsU? Cumulative GPA at PSU?

biave you ever been convicted of a crime other than a motnor treffic violation? Yes N_o If yes, attach full particulars on separate sheet.

Heve you a phybical deflelency which would limtt engaging in normal teaching activitien? Yes Wo. If yes, explain on soparate sheet or see Coordinator of supervised reaching.

Have you boen under constant medlcation and/or treatment for any long perlod of time? Yea wo If yes, explain on separate sheet or see Coordinator of supervised Teaching.

Are you now or have you been under paychlatric trentment? Yes Ho If yes, explain on separate sheet or see Coordinator of supervised Teuching.

Indieat below the number of guarter hours that you have completed succesefully in each of the following areas: 
Requirad Completed

Hinglah Composition

$3-6$

General Paychology

3

Eumar Developaent

3

*\$peech

3

* Studenta who take no college Speech course will be required to pass a spoch clearance test (avaliable only to graduate studenta).

Stgned

PERSONAL HISTORY FORM

Name Date

DIRECTIONS: Write a short autoblographical sketch of your life tellIng where you grev up, sehools attended, activities in school, hobbles, Interest, expariances with chlldren, whan and why you chose teaching as career and other thiags you think a professlomal aducator wight flad of Interest in considering you as prospective teachex. This account is to be handuritten with pen and 1nk. Checli spel11ng, gxamase, and general organization because thie vil1 be read by many people. Additlonal sheete may be atteched. 
Hane

bate

Nor the Advisor: (After completton, this page will not be avallable to the student.)

1. hiss this tudent consulted with you as often as semed destrable?

On entrance to college

Chengling major

To plan aach year's progras

To consult on changes in planned progran

Other

2. Do you know this studant?

Had student in class

lad an out-of-class concact in

kione

3. Is this otudent having academte difficulties?

Bankrupt

On probation

Low in jor of area of concentration

4. Would you coment, in a sentence or two, on your Inpression of this student as teuchor candidate at this tue in his preparation.

Name

Diviaion

After glving the student the cover whet and the last heec, rawove page 5 for your tiles. Please place the zenalning four shere of thie application in 1nterdepartmental mall addressed to: Dr. R. Allan Spanjex, School of Education, 201 01d Main. 
SECONDARY

RANE I.D. 110 QHONE DLGR

ADDRESS PsU sTuDarit TRANSEER STUDERT

CATALOG GRDDE LEVEL DAT TOTAL No. Has. (186)

Na. UPPER DIVISION HOURS (62)

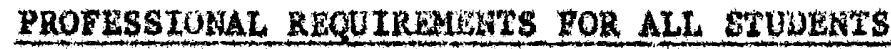

Prerequisite to student Teaching:

Pay 311 kuman Development:

Cd 312 Ed Esychology

Ed 314 Prin. of Sec. Teach, OR

Ed 408 Spec1al Sec. Kethods, OR Dept. Spec. Methoda
3

3

3
Ld 416 student Teaching 15

Ed 446 Philosophy of Education

Id 469 Developrental

kending

(Required for Junlor

High and sngliah. recomended for all othora)

\section{PROCRAM OP STUDTES}

List the preseat program, and the proposed program for the next 7 teras. Use penc11 wo change ean eas1ly be made.

Presant Tor 19

(Circle one: $\mathrm{F}, \mathrm{W}, \mathrm{s}$, ss) Coures Numbe:

Sth Term 19

$(\mathrm{F}, \mathrm{H}, \mathrm{s}, \mathrm{ss})$

Courae aumber:

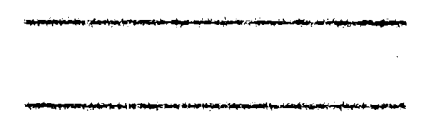

\section{Next Taru 19}

$(F, W, S, 85)$

Course Number: 3rd rorm 19 $(F, W, 5,85)$

Couras Lumber: 4th Tara

19 ( $),$ $s, \overline{s s})$

Course Number:

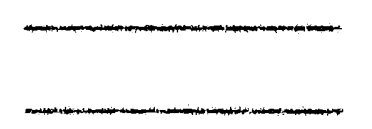

6th Tern 19

(T, H, S, SS)

Course Rumber:
7 th rem 19

$(i, k, s, S s)$

Course No.
Bth Texn

19 (F, W,

$\mathbf{s , \overline { s s } )}$

Course Sumber:

Checked through: 4 8 35 19 Advisor's 81gnature. 
APPENDIX C

APPLICATIOA FOR STUDENT TEACHLIU OR INTERASAIP

DIRECTIOUS FOR COKPLETING APPLICATION DOR STUDEST TRACHING OX INT ERWSHIP

\section{A. General Inatruction}

1. Return tixa corapleted application to the Supervised Tenching 0ffice, Room 201 O.M., before the deadilne date for the tera in whlch you wish to teach. Application recelved after this deadline w111 be placed on the walting 11 st. These deadlines are the first Friday of the regular academic term praceding the term of student teaching (fall trom atudent teaching applicants ast file by the end of the firet week of spriag taria).

2. Applieints should carafully check the Program of Studies for Teacher Education as outlined in the Portland State University catalog, If you have questions about your algibility for btudent teching, please sec your advisor.

3. Prerequiatces wich mut be wet before admianion to otudent reaching:

a. Admation to the Progran of Studies In Teacher ducation

b. A mintmum cumulative CRA of 2.30 , a GRA of 2.50 In protaselonal courses; and a CRA of 2.25 in areas of concantration for elanentary mejors; a 2.50 GPA in caaching major for weondary mors.

c. Completion of all prerequisitas stated in the PSU catalog. Including minim of 30 houra $1 \mathrm{n}$ realdence.

d. At least last quart $x$, funfor yox standing in college (123 hourt or mare)

e. Results of a TB x-ray ox tinte teat showling absence of comuntcable tubezculosis. T. B. clemrance is good for only one year frow the date 1t is read and wust be valld during the portod of student teachigg.

f. Approval of a faculty intarview comittee. 
3. Information

1. Following your Interview, the Selection and Retention Compttee w111 review your complete file and will natify you in writiog of the action taken on your application.

2. Although requests for specifle student teaching placentent will be taken Into consideraclon, the number of applicants. public sehool requirenents, and supervisory factors dictate final dec1 lons in regard to assigment of terms and tasching location: Thes must be made by the Supervised Teaching office In cooperation with the sehool districts where agreerueats have been established. 
ARPLICATION FOR ADAISSIOH TO STUDOKL TEACHING OR INTERNSUIP

Secondary reaching plezd Student Teaching

ilementary Areas (1) (2) Interashlp

Wr.

Mra. Miss $(\mathrm{fix} 8 \mathrm{t})$ (mIdd1e) (1ast) Phone

Present Address city State Ztp Code

Pextuanent Addrese city state 21p code

Alternate Phone where someone will know how to reach you

Please respond with checke of appropriate information:

Do you plan to graduate from PSU? Yes No... If "Yes", give date Do you hold a degree? Yel_._o . If "Yas", give college, degree and date.

Are you now enrolled in PSYT Yeg No. Date of Adalosion to PSU Note: Inrollment in evening or sumper alasses does not constitute admission to PSU.

Texw preferred for student taching: F

Yeax preferred for internihip: $197 \ldots$

Grade lavel prafarrad (number your cholces 1st, 2nd, and 3rd):

Elewentary $1{ }^{2} 3 \quad 4 \quad 5 \quad 6 \quad 7 \quad 8$

Secondary $7 \quad 8 \quad 9 \quad 10 \quad 11 \quad 12$

Type of experience prefarrad (number your cholcas 1st, 2nd, and 3rd or ito preferance)

Self-contained clasaroom, Flexible schaduling, Team toaching, Spectal progran (individual instruction) _. Diagnost1c toaching _, Integrated subject atter No preferonea Other - Inquiry

School jiatrlet preferred (number your chotces 1st, 2nd, and $3 x d$ or wo preference): 
Portland David Douglas _., Gresham , Lake Oawego _., Mitwaukle,

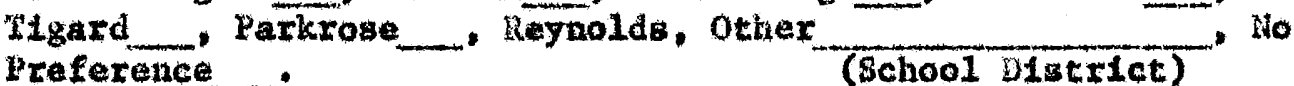

Type of transportation: Car Bus

I understand that student roaching or Internship is a planned program requiring the student's full attention and affort. Any regular outside cormituent whe as ather course or job responsibility is discouragad. If I feel it a necessity, before entering into auch a comitment, I ahall discuss the matter with the office of supervised reaching.

\section{(S1guature)}

Supplement to Application for student reaching or Internohtp (Th1 form should be comited as carefully as a job application as it will be sent to your achool to assiet in placement).

Name Phone

Address 21p

Nale Eanale Married Single

Name and ages of Hblings under 17

What schools do they attend?

Places Livad outeide of Multnomah County.

Work expertence

Grade and high school attended

Colleges attended

Areas in which I feel most comptent to teach

Foralga language solten 
Muslcal Instrumentio I can play

Arta and handicrafts I can supervise

Sports I can cosch

rravel expertences

Clubs and organlzatione (past and prasent). Ind1cate any offlees held.

Direct experiences with children (1nclude observation, teaching, Buperviaton. Nention age level, stze of group, duration of experience. BE SPECIFIC).

Reasons for bocoming a tencher and professtonal goals: 
Hane Age Term Year Eler sec

1. Admiseton Inforwation:

A.

Degree
Cert.
3. GA Area Area Prot. Curn. C. Defletency* (reason)

HaIvax no

2. Completion of Experience:

6. Interview Form:

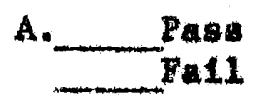

8. Lxtendod $\mathrm{kxp}$ How Long?

Ranson:

3. Block Brogram no

4. College Supervigor:

5. Final Evaluation Sheet: 1 2 3

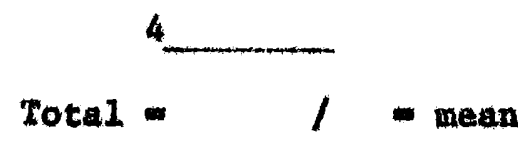

Comant:

$$
\text { I I U }
$$

1 Appearance Corr of Speech

2 3

Votce Ab111ty Rrevent Ideas

4 5 6 7 a Alertness Judgment Inotional stabl11ty Selfconf1dence

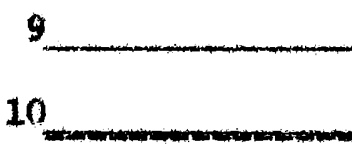
Priendilnes: Por Fitnes: for S.T.

Total

Mean

Pase W Raserv.

Rej

Comants: 
7. School Final Lvaluation Form:

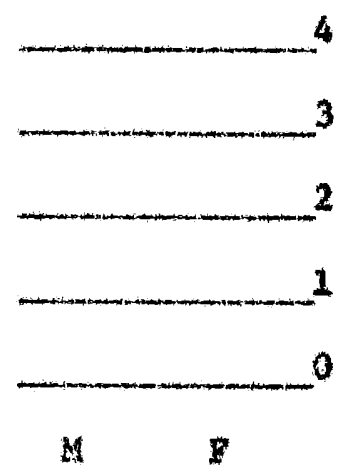

Commente: 
ARPENOLX

STUDEAT TEACHING EVALUATION

Fortland state University Rlacement Service

PO Box 751

Eortland, Oragon 97207

Student Teacher Collega supervisox

Assignmant Torn and Year (grade, subject, and gchool)

\section{(8chool District)}

(city and state)

This evaluation be done either by the suparvituor ox cooperatively by the supervisor and the student teacher upon satiofactory complation of the student tenching experience. It 18 based upors performance that can reasonably be expected of students in their first traching situacton. The student ho access to this evaluacion.

WWOWLDOGE OY SUHJECT MATTER:

Supertor Well preparad Adequate

TEACHIHO ABILITY: response to pup11s, cless organization, room sanagenent, to.

Outatanding Above avorage Adequate

ABILITI TO GET ALONG WITH OLHERS:

Especially profielent

Gets along reasonably well

EROFESTIOHAL ATTITUDES:

Alghly profesalonal Comendable Meets aninum standard:

COMMEN ON PEASONAL QUALIFICATIONS such as appearance, polse, tact, dedication, potential, etc. 


\section{APPENDIX F}

\section{SCORING SCALE USED TO DETERMINE STUDENT TEACHER'S SCORE ON \\ FINAL EVALUATION FORM}

KANOWLEDGE OF SUBJECT MATTER:

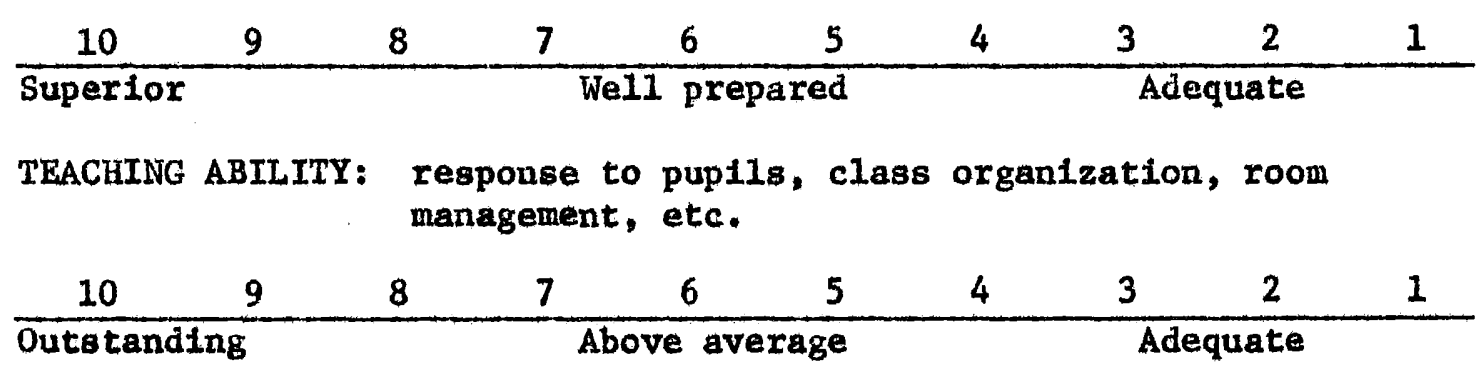

ABILITY TO GET ALONG WITH OTHERS:

$\begin{array}{lllllllll}10 & 9 & 8 & 7 & 6 & 5 & 4 & 3 & 2\end{array}$

PROFESSIOHAL ATTITUDES:

\begin{tabular}{llllllllll}
10 & 9 & 8 & 7 & 6 & 5 & 4 & 3 & 2 & 1 \\
\hline High professiona1 & \multicolumn{3}{c}{ Commendable } & & Meets minlmum standards
\end{tabular}


APPENDIX G

INTERVIEW FORHI

STUDEWT'S RAME DATE

Each student io acreened in the ducation office for complation of minimun course and $8 . p .4$. requi rements. For purpoges of the interviow please moke a judgment about the candidate by rating each of the followling traite as high, average, or low, underlining particulaz charectertetics, writhos commente, etc.

1. APEZAZANCE. Thet sort of f1rst Impression does he hake? Does he look like a heelthy and energetic pereon? llew hodily or fectal characteristics which might aerlously hamper him? Is be wellgroomed or lovenly? Attrective or unattractive in appearance?

2. CORAECINESs OF SPEECH. Does be speak granatically correct Englieh or does be make frequent gramentical errors? is his cholce of worda accurate?

3. vorce. Is the appllcant' volce irritating or plensant? Can you easlly heax whet he ays? Does he muble or talk with an accent which offends or baffles the listener? Is hie apeech clear and distinct, his volce so vell modulated that it is a valuable anset?

4. ABILITY TO PRESERT IDEAS, Doen he speak logleally and convinelugly? Or doen he tend to be vague, confused, or $1110 \mathrm{~g} 1 \mathrm{cal}$ ?

5. ALERTWESS. How zeadily does he grasp the meaning of a question? Is the slow to comprehend obvious polnte? Doas ha underotand quickly, oven though the 1dea is new, Involved, or diffleult?

6. JUDGMari. Does ho Impress you as a person whose judgment would be dependable even under stress? Is he hadty, exratic, or enotional? It he blased?

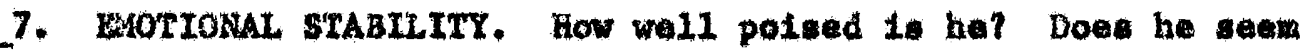
touchy, ensitive to critlelom, exeliy upset? Is he easily irritated? Is he Impatient? 
8. SEth-CON IDUich. Does he seem to be uncertain of hingelf, hasitant, lacklng in assurance? Is ha solf-confident and assured?

9. FRIENDLINESS. Is the a friend1y, likeable peraon? W111 his colleqgues and atudents be drawn to him? Is he ratiring or unfriendly?

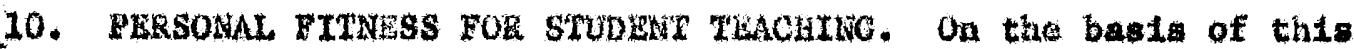
Interview, how do you rate thi candidat 's interest in teaching and sultability for student teaching?

FASS (Coment rould be helpful)

PASS WITi desenvatIoNs (Coment required)

REJECT (Coment required)

comperts: 
APPLNDTX I

\author{
PORTLAND STATE UWTVERSITY \\ SCHOOL OH EDUCATION \\ ORFICE OF SUPERVISLD THACHINC
}

Md-Tara Student Teachax Report

Name of studont School

Grade or Subject:

Please review your evaluntion with the student and return this oneet to the supervisor no later than

We belleve that every student has some otrengthe and owe weaknesses as an Individual and that it is only through his knowledge and understanding of his personil atrength and weaknesses that he is able to grow as a teacher. Parts A and B refer to the atudent as an Individual. Rarte $C$ and $D$ refer to whatever etandard you feel any atudent must attain before beginning teaching on his own.

A. Pleave coment on this student's strengthe as a prospective teacher.

B. Plase conent on this student's weaknesses as a prompective teacher.

C. Rlease make a judgent at this time as to this student's readiness for beglaning teaching on his own.

Seens capable, hould be ready by the conclusion of the student teaching experience.

May need an extended atudent tenching experience.

It 18 doubtful if this student 111 be able to develop the qualities nacessary to begin taaching and should be withdrawn. 
other.

D. Blease make a fudgment at this time as to tha gtadent's probable success as a teacher. $(x)$

Excellent Good Falr Foor Unacceptable




\author{
APPEKDIX I \\ PORTLAND STATC UKIVERSITY \\ SCHOOL OF EDUCATION \\ OFRICE OF SUPLVISWD TACATIN
}

\title{
I1nel Studant Teacher Report
}

Hane of student. Sehnol

Grade or Subject

Pleasa return this shet no later than

We believe that every student has some strengths and some veaknesgee as an Individual and that it is only through his knowladge and understanding of his personal strangths and weaknases that he is able to grow as teacher. Parta $A$ and $B$ refer to the student as as 1adividual. garte $C$ and $D$ refer to watever standard you fael any gtudent wut attain before beginning teaching on his own.

A. Please coment on this otudent's strength a a prospective teacher.

B. Please coment on this student' veaknewses as a prospective teacher.

c. Please make a judgment at this time as to the student's readineas for beglaning teaching on his own.

\author{
_ Ready at this time. \\ Heeds an extended student teaching experionce in
}

It 1s doubtful if this student will be able to devalop the qualities nacessary to begin teaching and should not pase. 
other.

W. Please make a judgment at this time as to the student's probable success as teacher.

Outotand1ng ___ood ___fverage __Below Average Unacceptable 